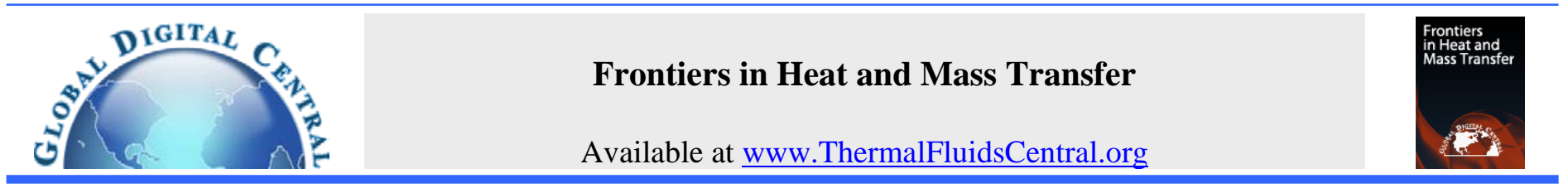

\title{
RECENT DEVELOPMENTS IN HIGH TEMPERATURE HEAT EXCHANGERS: A REVIEW
}

\author{
Xiang Zhang, Hadi Keramati, Martinus Arie, Farah Singer, Ratnesh Tiwari, Amir Shooshtari, and Michael Ohadi \\ Advanced Heat Exchangers and Process Intensification Laboratory \\ Department of Mechanical Engineering \\ University of Maryland, College Park, MD 20742, United States
}

\begin{abstract}
Heat exchangers are key components of most power conversion systems, a few industrial sectors can particularly benefit from high temperature heat exchangers. Examples include conventional aerospace applications, advanced nuclear power generation systems, and high efficiency stationary and mobile modular fossil fuel to shaft power/electricity conversion systems. This paper provides a review of high temperature heat exchangers in terms of build materials, general design, manufacturing techniques, and operating parameters for the selected applications. Challenges associated with conventional and advanced fabrication technologies of high temperature heat exchangers are discussed. Finally, the paper outlines future research needs of high temperature heat exchangers.
\end{abstract}

Keywords: High Temperature, Heat Exchanger, Advanced Manufacturing, Additive Manufacturing, Material Selection.

\section{INTRODUCTION}

High temperature heat exchangers (HTHXs) are described in the literature as operating above an arbitrary value of $500^{\circ} \mathrm{C}$, and early development of HTHXs was motivated by the first oil shock in 1973, which created a demand for energy saving and more effective use of energy (Mori et al., 1986). Since then, various types of HTHXs have been developed, and many have been used as recuperators for gas turbine engines, aerospace, hydrogen production, waste heat recovery, supercritical $\mathrm{CO}_{2}$ power cycles, and high temperature fuel cell systems (Crosbie and Chapin, 2003; Mansilla et al., 2007; Magistri et al., 2006; Musgrove et al., 2014; Johnson et al., 2008). Heat exchangers operating at such high temperatures are subject to unique material challenges such as creep, reduced strength at higher temperatures, oxidation of material, corrosion, and thermal shock. As a result, expensive alloys that retain their strength at elevated temperatures are typically the material of choice. However, these alloys typically have low thermal conductivity, and difficult manufacturability (Marlin Steel, 2016; Continental Steel \& Tube Company, 2015), and thus they present their own challenges in heat exchanger design and fabrication. Even these alloys lose strength at elevated temperatures. This low strength at higher operating pressures means that the walls must be thicker, requiring more material. Thick wall geometry makes the HTHXs made of expensive alloys cost prohibitive in most power cycle applications. One way to offset these costs is to develop compact heat exchangers that have higher surface area to volume ratio and thus reduce the amount of material needed. As a result, in past couple of decades, there has been increased interest in development of compact and cost effective HTHXs (Ohadi and Buckley, 2001; McDonald, 2000). Advanced manufacturing techniques, mainly additive manufacturing of metals, have recently shown promising results in fabricating compact HTHXs with innovative heat transfer surface designs (Zhang et al., 2015). This paper provides insights into challenges being encountered in the development of HTHXs, including material selection and recent developments in design and application areas of HTHXs.

\section{MATERIAL SELECTION}

Materials are key to the economic design of HTHXs. Materials are selected for an HTHX for a particular application based on a combination of mechanical properties (e.g., strength, creep resistance, fatigue), thermal properties (e.g., thermal expansion, thermal conductivity), chemical properties (e.g., oxidation, corrosion), manufacturability (e.g., machining, joining), and overall cost. Material selection may also depend upon the heat exchanger design itself. For example, a design which accommodates thermal expansion of the heat exchanger components can use lower cost materials (e.g. SS347) with inferior creep properties in place of expensive alloys (such as Ni-based alloys). Also, applications such as those of the aerospace sector are more sensitive to the overall weight and shape of HTHX than the cost of heat exchanger itself.

Most materials used at lower temperatures, such as steel, copper, and aluminum, lose their thermo-mechanical properties at elevated temperatures. For this reason, they cannot be used for HTHX applications. Rather, materials which can retain their properties at high temperatures, such as high-grade steels and Ni-based alloys, are used for HTHXs. The maximum allowable stresses of some high temperature material candidates for HTHXs for Super critical $\mathrm{CO}_{2}\left(\mathrm{sCO}_{2}\right)$ application are shown in Fig. 1 and Fig. 2. As shown there, most of these materials lose strength at temperatures exceeding $550^{\circ} \mathrm{C}$ and particularly above $600^{\circ} \mathrm{C}$. Depending upon the operating temperature and pressure, high temperature materials can vary from ferritic steels to Ni-based alloys and ceramics. The prices for the material can vary from $\sim \$ 2-3 / \mathrm{kg}$ for ferritic steel to $\sim \$ 70 / \mathrm{kg}$ for Ni-based alloys (Brun et al., 2017). Apart from the strength, the material should also be resistant to thermal fatigue and creep rupture for a combination of high temperature and high pressure conditions.

*Corresponding author.Email: ohadi@umd.edu 


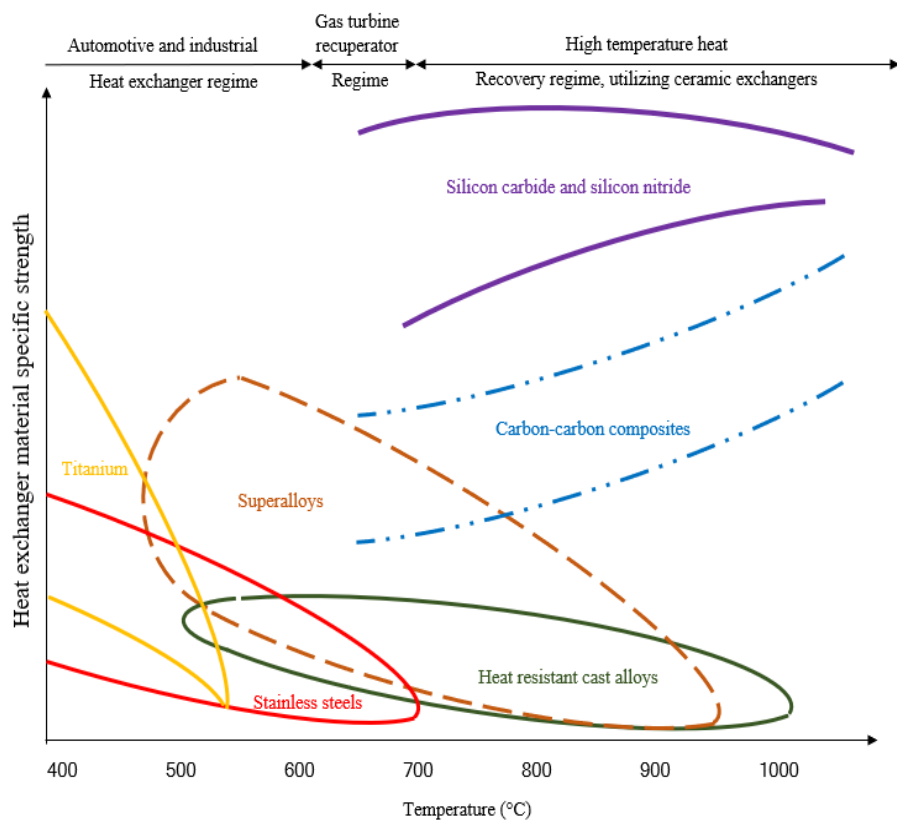

Fig. 1 Temperature ranges for heat exchanger materials (adapted from reference (McDonald, 1980))

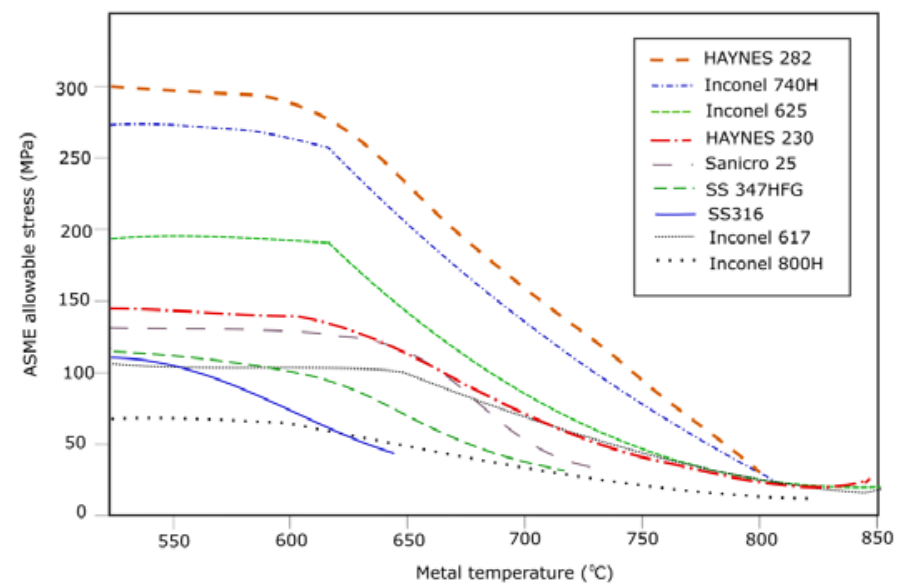

Fig. 2 Strengths of various iron- and nickel-based alloys showing that most of the materials lose strength at higher temperatures (adapted from references (Brun et al., 2017) and (Chordia et al., 2017))

As the development of HTHXs is gaining momentum, research is being conducted on new high temperature materials such as high temperature alloys and ceramics, fabrication and joining methodologies, and material compatibility with the working fluids for different applications (Chordia et al., 2017; Lewinsohn et al., 2012). It is beyond the scope of this paper to include all the possible materials and their applicability for different applications, as they vary depending upon the operating conditions, working fluid and their chemical interaction with the heat exchanger material. However, this section will provide a summary of materials currently being considered for major HTHX applications.

\subsection{Metals}

Metals are the first choice for high temperature heat exchanger applications due to their excellent thermomechanical properties as well as manufacturability. However, as the operating temperatures rise beyond $\sim 600^{\circ} \mathrm{C}$, the cost of materials increases exponentially due to steep decrease in material strength. Metallic heat exchanger materials can be divided into iron-based alloys and nickel-based superalloys. Iron-based alloys such as SS316 and SS347 have good mechanical properties up to $550^{\circ} \mathrm{C}$ and $600^{\circ} \mathrm{C}$, respectively, but are limited in corrosion resistance at high temperatures. Nickel-based alloys with chromium are both strong and corrosion resistant at high temperatures. It should be noted, however, that the cost of Ni-based alloys is about 3 to 10 times higher than ironbased alloys (Chordia et al., 2017). Hence, iron-based alloys are preferred in applications up to $600^{\circ} \mathrm{C}$ in many recuperator designs, provided that corrosion and creep do not present any issues.

\subsubsection{Iron-based Alloys}

Given their mechanical properties and resistance to corrosion, iron-based alloys such as the AISI 600 series of superalloys should be considered as the first choice for moderately high temperature applications (Smyth, 1997). For example, type 347 austenitic stainless steel is widely used as material for recuperators that operate at temperatures up to $600^{\circ} \mathrm{C}$ (Aquaro and Pieve, 2007; McDonald, 2003). However, severe corrosion may develop for type 347 austenitic stainless steel recuperators that operate above $650^{\circ} \mathrm{C}$ (Sunden, 2005). At temperatures above $700^{\circ} \mathrm{C}$, film instabilities cause oxidation, cracking with spallation, and $\mathrm{Cr}$ depletion. Furthermore, cracking can accelerate oxidation by breaching the protective layer (Aquaro and Pieve, 2007). On the other hand, high temperature ferritic steels can be used for environments with fusion and fission neutron irradiation up to temperatures reaching $750^{\circ} \mathrm{C}$. Ferritic steels also can be used for lead/bismuth, while silica bearing steels can be used for sulfuric acid thermal decomposition (Sunden, 2005).

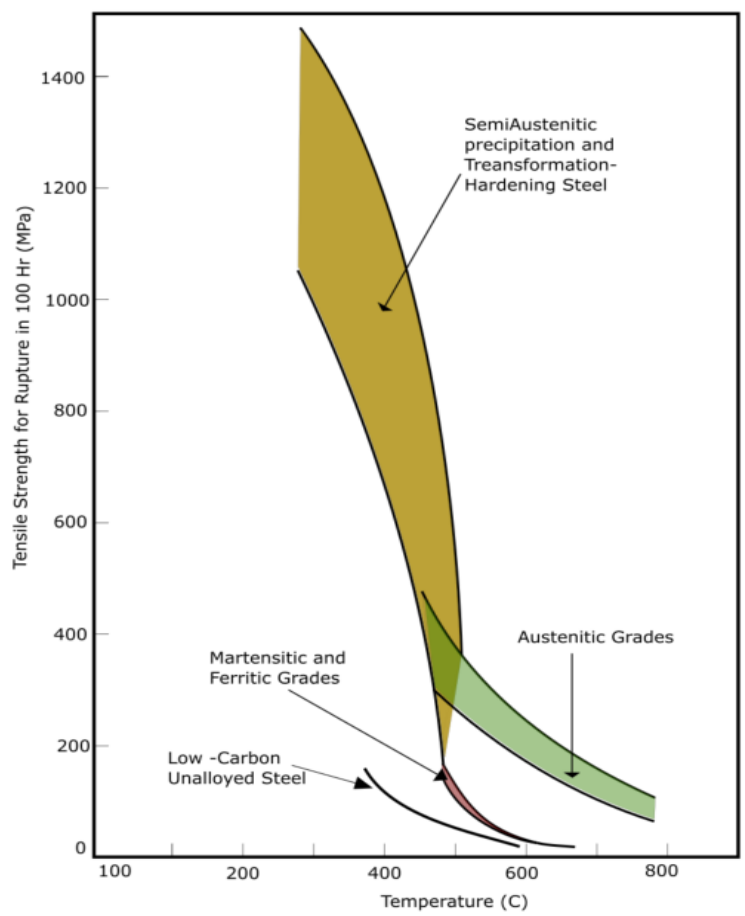

Fig. 3 Comparison of the hot-strength of stainless steels with low carbon alloyed steels at high temperatures (adapted from reference (American Iron and Steel Institute) )

The tensile strength of different steels for the range of temperatures is shown in Fig. 3. The tensile strength of austenitic, martensitic and ferritic stainless steel is higher than that of low-carbon steels. Although semi-austenitic steels show significantly high hot-strengths at low temperature, they are not suitable for temperatures higher than $650^{\circ} \mathrm{C}$ (Nikulin et al., 2010).

Some modifications to stainless steel 347 is claimed to increase its operating temperature up to $750^{\circ} \mathrm{C}$ and increase its creep resistance, compared to standard 347 stainless steel (Aquaro and Pieve, 2007). In 
this vein, researchers have conducted studies on new advanced alloys to mitigate problems which limit the temperature capability of 347 stainless steel foils and sheets for recuperator applications (Maziasz and Swindeman, 2003). Through some accelerated oxidation and creep tests in an exhaust gas environment at $650-750^{\circ} \mathrm{C}$ it has been demonstrated that HR120 and AL20-25+Nb alloys can sustain higher temperature, cyclic operation, and more corrosive environments (Maziasz et al., 2007).

\subsubsection{Nickel-based Superalloys}

Nickel-based alloys exhibit better mechanical and corrosion resistance properties at higher temperatures than iron-based materials. These materials can operate at temperatures as high as $816^{\circ} \mathrm{C}$. For example, selected Inconel alloys, which are a family of austenitic nickelchromium-based superalloys, are suitable for environments subjected to high pressure, high temperature, and corrosion (Special Metals, 2012). Heat treatment, such as annealing, of Inconel and its chromium content make it more suitable for corrosive environments than iron-based alloys (Panel, 2014). In addition, while the molybdenum content of Inconel improves strength, its aluminum content improves oxidation resistance, and similarly, the nickel content improves its corrosion resistance (Zhang and Seiya, 2015; Magrab et al., 2009). Other nickel-based alloys commonly used in the high temperature applications are from the Haynes family. Some of the properties of Inconel alloys are presented in Table 1.

Table 1 Thermal properties of Inconel alloys (United performance metals, 2018; Special Metals, 2012)

\begin{tabular}{|l|l|l|l|}
\hline Alloy & Assay & $\begin{array}{l}\text { Thermal } \\
\text { conductivity } \\
(\mathrm{W} / \mathrm{m}-\mathrm{K})\end{array}$ & $\begin{array}{l}\text { Coefficient } \\
\text { of thermal } \\
\text { expansion }\end{array}$ \\
\hline Alloy 625 & $\begin{array}{l}\text { Ni-balance, Cr-23, } \\
\text { Mo-10, Fe-5, minor } \\
\text { Cb, Mn, Al, Ti }\end{array}$ & $7-25.3$ & $12.8-16.2$ \\
\hline Alloy 600 & $\begin{array}{l}\text { Ni-72, Cr-17, Fe-10, } \\
\text { minor C, Mn, Si }\end{array}$ & $8.6-16.7$ & $8.4-9$. \\
\hline Alloy 601 & $\begin{array}{l}\text { Ni-63, Cr-25, minor } \\
\text { Al, Fe, Mn, Si }\end{array}$ & $11.2-27.8$ & $7.6-10.18$ \\
\hline Alloy 617 & $\begin{array}{l}\text { Ni-45, Cr-24, Co- } \\
\text { 15, Mo-10, minor } \\
\text { Al, Fe, Mn, Si }\end{array}$ & $13.4-28.7$ & $6.4-9.2$ \\
\hline Alloy 718 & $\begin{array}{l}\text { Ni-55, Cr-21, Cb-5, } \\
\text { minor Mo, Ti, Al }\end{array}$ & 6.5 & $5.9-8.9$ \\
\hline Alloy HX & $\begin{array}{l}\text { Ni-47, Cr-23, Fe-20, } \\
\text { Mo-10, minor C, } \\
\text { Mn, W, Cu, P }\end{array}$ & $9.1-27.2$ & $7.4-9$. \\
\hline Alloy X-750 & $\begin{array}{l}\text { Ni-70, Cr-16, Fe-9, } \\
\text { Ti-2.75, minor Cu, } \\
\text { Co, Al }\end{array}$ & $9.7-23.63$ & $6.5-9.8$ \\
\hline Alloy C-276 & $\begin{array}{l}\text { Ni-balanced, Mo- } \\
\text { 17, Cr-16.5, Fe-7, } \\
\text { minor W, Mn }\end{array}$ & $10.2-19$ & $5.9-11$ \\
\hline
\end{tabular}

The ASME Boiler and Pressure Vessel and Process Piping Code (2010) has recently approved the use of Inconel $740 \mathrm{H}$ for temperatures up to $816^{\circ} \mathrm{C}\left(1500^{\circ} \mathrm{F}\right)$, and the recommended use temperature of this material has been suggested as $760^{\circ} \mathrm{C}\left(1400^{\circ} \mathrm{F}\right)$. Haynes 282 , which has mechanical properties slightly superior to Inconel $740 \mathrm{H}$ (Fig. 2), is in the process of approval by ASME. The third-best alloy among those considered in this review in terms of mechanical strength is Inconel 625. Nickel-based materials have also shown good corrosion resistance properties. For example, a recent study on the corrosion behavior of various iron-based and nickel-based materials showed that higher iron and nickel-based alloys were relatively unaffected in a supercritical $\mathrm{CO}_{2}$ environment (Pint and Keiser, 2016).

\subsection{Ceramic}

Although metals have advantages such as manufacturability, strength, ductility and weldability, their use in HTHXs is limited at very high temperatures. Ceramic materials, however, have excellent temperature resistance as well as corrosion resistance, making them the material of choice for HTHXs. Heat exchangers made out of ceramic materials have higher temperature capability, good corrosion and creep resistance, and low material cost, but low pressure containment capability compared to metal heat exchangers (Li et al., 2011).

Ceramics have crystalline or partly crystalline structures and are produced from essentially inorganic, non-metallic substances. These materials are solidified from molten mass by cooling and are typically post-processed by heating. They can be divided into two types: 1) monolithic and 2) ceramic matrix composites (CMCs). Monolithic ceramic materials have a single constituent such as silicon carbide, silicon nitride, zirconia, or alumina, and are brittle and have low tension strength. Except silicon carbide and silicon nitride, other ceramics are prone to thermal shock due to large thermal gradients. This causes HTHXs made of these materials to suffer from lack of reliability (Luzzatto et al., 1997). Table 2 shows thermal properties for most common ceramic materials. Thermal shock resistance, high temperature capability, and corrosion resistance are the main reasons to select a ceramic heat exchanger material (Sunden, 2005). Silicon carbide has high strength, high hardness, low weight, and low thermal expansion, making it a suitable heat exchanger material. Silicon carbide materials are kinetically stable up to $1000^{\circ} \mathrm{C}$. However, rapid oxidation begins at temperatures ranging from 1000 to $1150^{\circ} \mathrm{C}$ and becomes significant at $1650^{\circ} \mathrm{C}$ (Zhang and Seiya, 2015).

Monolithic ceramic materials are brittle and cannot withstand pressure. Except for silicon carbide and silicon nitride, ceramics cannot resist large thermal gradients. Monolithic ceramics thus suffer from lack of reliability (Luzzatto et al., 1997). To address this problem, ceramic matrix composites (CMCs) were developed to improve the thermal shock resistance, hardness, and high temperature stability (Sommers et al., 2010).

CMCs on the other hand, consist of two morphologically different phases: ceramic fibers, or the reinforcement phase, embedded in a matrix phase, which offers improved toughness compared to regular ceramic. Most common types of CMCs are carbon/carbon, carbon/silicon carbide, and silicon carbide/silicon carbide. The properties of CMCs depend on parameters such as type of reinforcement, length and diameter ratio, and chemical compatibility (Luzzatto et al., 1997). Two-dimensional forms of reinforcement can also be used to improve the mechanical properties of CMCs. For example, two-dimensional fiber reinforced $\mathrm{C} / \mathrm{C}$-SiC such as Schunk CF226/2P77, DLR silica XS, and DLR silica XG have better hardness properties than short fiber reinforced CC-SiC materials such as Schunk FU2952, SGL carbon sigrasic, Brembo CCM, and DLR silica SF (Krenkel and Berndt, 2005).

Although ceramics have good thermo-mechanical properties, manufacturability, fabrication and mechanical joining remains a concern for their use in heat exchanger applications. Manufacturing of the primary component involves processes such as powder sintering and dry pressing. Unlike the metallic components, though, the ceramic components are limited in the type of primary shapes that can be formed economically. Further, joining of these primary components is a challenge, as mechanically joining these components is not reliable due to the brittle nature of the material. Many ceramic heat exchanger designs thus use the block structure of primary components, which are further machined and are bonded together inside an oven (Schulte-Fischedick et al., 2007; Schmitt et al., 2005). However, in recent years, some newer bonding techniques, such as laser welding, have shown promise for joining ceramic components (Rohde et al., 2009; Lippmann et al., 2004). Given their advantage of working at high temperatures and the general push to achieve higher thermal efficiencies, further developmental efforts are expected in the near future. 
Table 2 Thermal properties of ceramic material (Smyth, 1997; AZO Materials, 2018; Nielsen, 2000; Visaria et al., 2011)

\begin{tabular}{|c|c|c|c|c|}
\hline $\begin{array}{l}\text { Ceramic } \\
\text { material }\end{array}$ & Properties & $\begin{array}{l}\text { Maximum } \\
\text { operating } \\
\text { temperature } \\
\left({ }^{\circ} \mathrm{C}\right)\end{array}$ & $\begin{array}{l}\text { Thermal } \\
\text { conductivity } \\
(W / m-K)\end{array}$ & $\begin{array}{l}\text { Melt } \\
\text { point } \\
\left({ }^{\circ} \mathrm{C}\right)\end{array}$ \\
\hline $\begin{array}{l}\text { Silicon } \\
\text { carbide } \\
(\mathrm{SiC})\end{array}$ & $\begin{array}{l}\text { Good thermal } \\
\text { shock resistance, } \\
\text { flexural strength, } \\
\text { chemically inert, } \\
\text { high thermal } \\
\text { conductivity }\end{array}$ & 1400 & $3.8-20.7$ & 2837 \\
\hline $\begin{array}{l}\text { Silicon } \\
\text { nitride } \\
\text { (Si3N4) }\end{array}$ & $\begin{array}{l}\text { Vulnerable to } \\
\text { oxidation at } \\
\text { temperatures } \\
\text { exceeding } \\
1000^{\circ} \mathrm{C}\end{array}$ & 1900 & $10-43$ & 1900 \\
\hline $\begin{array}{l}\text { Alumina } \\
\text { (Al2O3) }\end{array}$ & $\begin{array}{l}\text { Lower thermal } \\
\text { shock resistance } \\
\text { than silicon } \\
\text { carbide and } \\
\text { silicon nitride }\end{array}$ & $1500-1700$ & $12-38.5$ & 2050 \\
\hline $\begin{array}{l}\text { Zirconia } \\
\text { (ZeO2) }\end{array}$ & $\begin{array}{l}\text { Cannot } \\
\text { withstand large } \\
\text { thermal } \\
\text { gradients, low } \\
\text { thermal } \\
\text { conductivity in } \\
\text { cubic phase } \\
\text { (thermal barrier } \\
\text { coating) }\end{array}$ & $\begin{array}{l}\text { Depends on } \\
\text { stabilization } \\
\text { (up to } \\
\text { 2400) }\end{array}$ & $1.7-2.7$ & 2700 \\
\hline $\begin{array}{l}\text { Aluminum } \\
\text { nitride } \\
\text { (AlN) }\end{array}$ & $\begin{array}{l}\text { Good oxidation } \\
\text { resistance and } \\
\text { thermal stability } \\
\text { up to } 1300^{\circ} \mathrm{C}\end{array}$ & 1300 & $60-177$ & 2200 \\
\hline
\end{tabular}

\section{TYPES OF HIGH TEMPERATURE HEAT EXCHANGERS}

As discussed previously, the cost of HTHX increases exponentially as the operating temperature increases, particularly above $600^{\circ} \mathrm{C}$, mainly due to the material cost as well as manufacturing cost of the superalloy and ceramic heat exchangers. Higher pressure applications such as those encountered in the power cycles complicates the issue even further. The majority of conventional heat exchanger designs used in low temperature applications prove to be uneconomical at high operating temperatures. The high cost of exchangers in power plant applications such as supercritical $\mathrm{CO}_{2}$ Brayton cycles is a major stumbling block to making the cycle economical (Chordia et al., 2017).

As a result, newer designs of heat exchangers that utilize the materials more efficiently, namely higher surface area to volume ratio designs, are being developed (Chordia et al., 2017; Zhang et al., 2015). These designs typically use microchannels as well as fin geometries to accomplish the higher area. An added advantage of smaller channel sizes is that the heat transfer in such miniature geometries is much higher (Arie et al., 2017; Kandlikar et al., 2005). Advances in manufacturing processes, such as $3 \mathrm{D}$ printing, have helped engineers to fabricate designs which are difficult to fabricate otherwise (Arie et al., 2016; Gerstler and Erno, 2017). The present section reviews various heat exchanger types and designs including the conventional designs utilized in high temperature applications.

\subsection{Plate-fin Heat Exchanger (PFHX)}

Plate-fin heat exchangers (PFHXs) are one of the most commonly utilized HTHXs for diverse industrial sectors. They are used mainly for gas-to-gas heat transfer applications. The main components of a PFHX, including side bars, fins, and parting sheets, are shown in Fig. 4. The fins are usually fabricated using a stamping process and are brazed together with the base plates. A brazed PFHX can withstand a maximum pressure of 90 bar, while diffusion bonded PFHXs can be used under pressures up to 200 bar (Chordia et al., 2017).

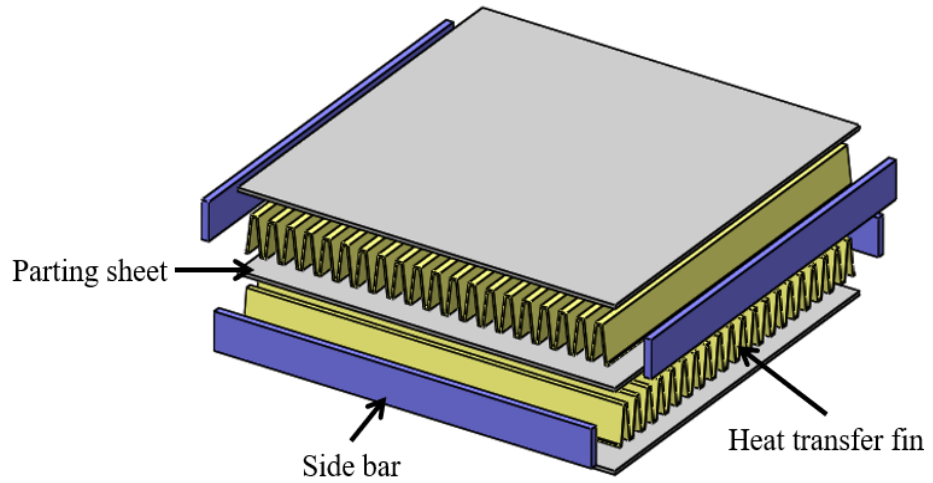

Fig. 4 Illustration of main components of PFHX

The fins in PFHXs can be easily rearranged, which allows the PFHXs to operate in any of the cross-flow, counter-flow, or crosscounter-flow configurations. The main applications for PFHXs at high temperatures are gas turbine and power plants for hot gas heat recovery. Generally, PFHXs have a good heat transfer area to volume ratio and hence can be compact and economical for high-temperature applications (Chordia et al., 2017).

\subsection{Plate-and-frame Heat Exchanger}

Plate-and-frame heat exchangers are often used to transfer heat between two liquids or two gases. The fluid-separating plates of these heat exchangers are typically manufactured by compression processing of a thin metal sheet, and they come in several patterns such as wavy, chevron, washboard, herringbone, cross-corrugated, cross-undulated, or crosswavy (Utriainen and Sundén, 2002; Stasiek, 1998; McDonald, 2000; Foerster and Kleemann, 1978). Two such heat transfer plates are then stacked to produce a single cell, and this process is repeated to manufacture the required number of cells. The structural strength of the core is achieved through the connection of the end plates once all the cells are stacked, as shown in Fig. 5 (Seo et al., 2015). For high pressure applications, the plates can be welded or brazed together to ensure operation up to 200 bar pressure and $815^{\circ} \mathrm{C}$ temperature (Shah and Sekulic, 1998). Two layouts are typically used for plate-and-frame heat exchangers in recuperators in microturbine systems: 1) rectangular designs, which are installed behind the rotating machinery, and 2) annular designs, which are wrapped around the turbine (Lara-Curzio et al., 2002; McDonald, 2000).

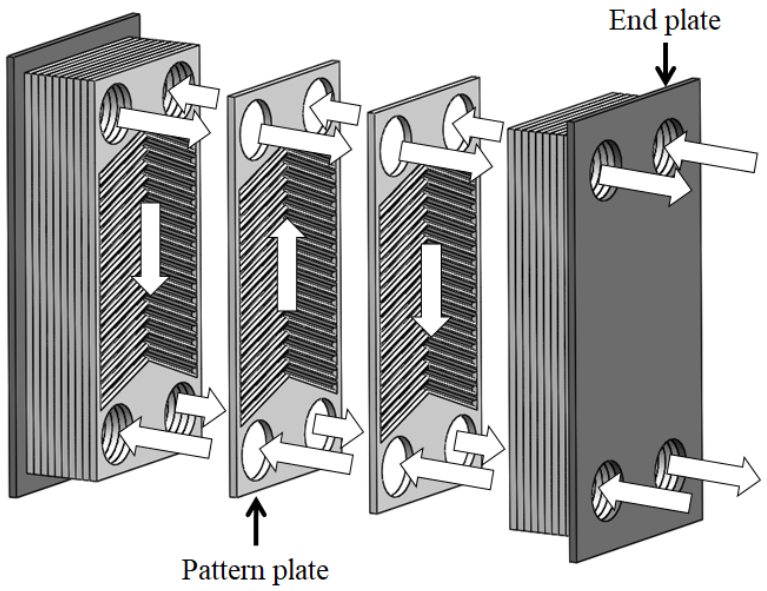

Fig. 5 Plate-and-frame heat exchanger structure concept 


\subsection{Shell-and-tube Heat Exchanger}

Shell-and-tube heat exchangers (Fig. 6) are the most common type used in industry. The tube diameters vary from 0.625 ” to 1.5 ” ( $16 \mathrm{~mm}$ to 38 $\mathrm{mm}$ ) in conventional heat exchangers. These heat exchangers have very low surface area to volume ratio and hence are generally not economical for high-temperature and high-pressure applications. Chordia et al. ( 2017), however, developed a shell-and-tube heat exchanger with a large number of tubes of diameter close to $1 \mathrm{~mm}$ to achieve small wall thickness and very high surface area to volume ratio. Since the channels are on the order of millimeters or less, the heat exchanger benefits from the high heat transfer. Since this type of heat exchanger can handle more severe conditions and higher pressures and temperatures, it can be used in gas turbine systems if there is no space limitation. It can also be used as a high temperature gas-cooled reactor for nuclear heat utilization.

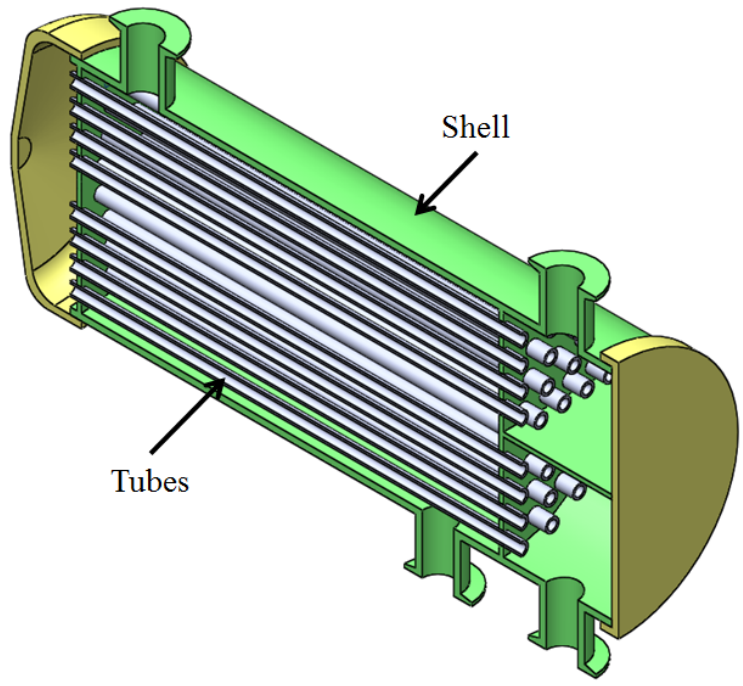

Fig. 6 Shell-and-tube heat exchanger structure concept

\section{HTHX FABRICATION USING ADVANCED MANUFACTURING TECHNIQUES}

Processing, machining, welding and brazing of superalloys is difficult due to their higher toughness, low thermal conductivity, tendency to crack during welding, or the unavailability of suitable brazing materials (Marlin Steel, 2016; Continental Steel \& Tube Company, 2015; David et al., 2015). Specialized equipment and highly trained operators are often needed for processing such materials.

However, new developments in advanced manufacturing techniques such as 3D printing can address the challenges faced by conventional manufacturing. This section discusses HTHXs fabricated using various advanced manufacturing techniques such as additive manufacturing and photo-chemical etching processes.

\subsection{Additive Manufacturing}

Additive manufacturing (AM), also known as 3D printing, emerged nearly three decades ago and was initially used mainly for quick prototyping and production of specialized parts. However, due to its high degree of freedom, especially for fabrication of complex parts, there has been significant development of industrial-scale 3D printers since then. 3D printers now can print various metals, ceramics, and other tough-tomachine materials. As a result, AM has evolved from prototyping purposes to production of complex parts used in industries such as aerospace, biomedical, oil and gas.

There are three major metal-based AM techniques: selective laser melting (SLM), direct metal laser sintering (DMLS), and electron beam melting (EBM). SLM and DMLS printers usually consist of two platforms. The first platform is a powder dispenser platform that houses the metal powder. The second platform is the build platform on which the 3D structure is built. After a layer of the 3D structure is built, the powder dispenser platform rises while the build platform lowers, so a new layer of powder can be distributed on top of the existing layer. A re-coater arm is used to uniformly distribute the metal powder, as shown in Fig. 7. In the case of DMLS, the metal powder is sintered using a laser just below its melting temperature. For the case of SLM, the powder is completely melted. Lenses focus the laser beam while a scanning mirror controls the beam or spot location based on a slicing of the 3D structure CAD file. The process is repeated until the entire 3D structure is built. The EBM process is similar to that of SLM. The major difference is that an electron beam is used instead of a laser to melt the powder. Due to the use of the high-power electron beam, parts fabricated using EBM will have better mechanical strength than parts fabricated using the SLM or DMLS process.

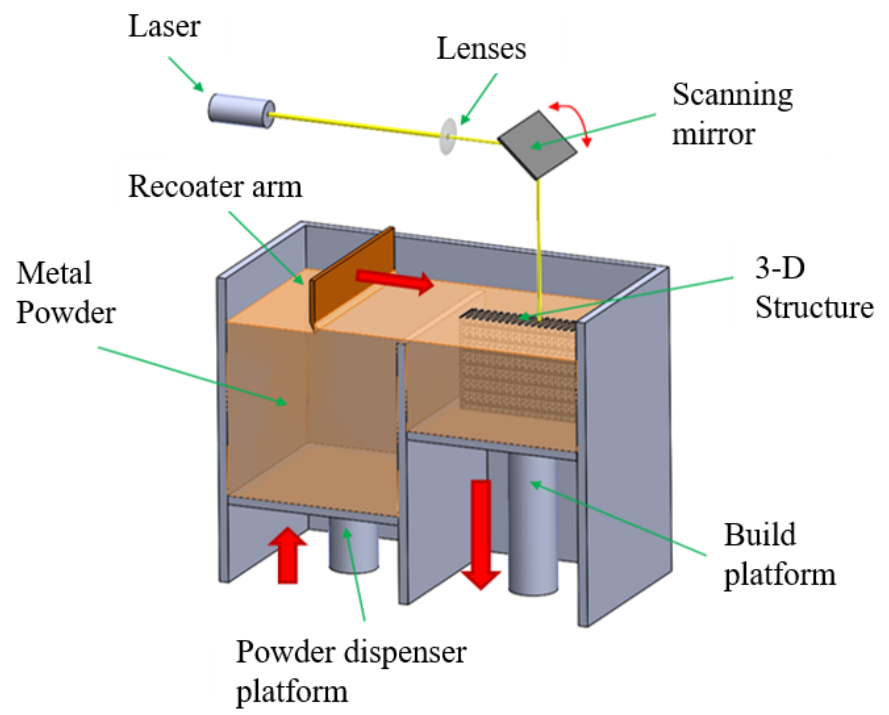

Fig. 7 DMLS/SLM concept (Arie, 2016)

Laminated object manufacturing (LOM) is another AM technique capable of fabricating metal heat exchangers. In the LOM process, a 3D structure is built layer by layer by cutting a sheet of material using a laser. A heated roller bonds the build part in the current layer onto the previous layer. The process is repeated until the entire $3 \mathrm{D}$ structure is built. Compared to DMLS and SLM, the LOM process is simpler and cheaper. In addition, LOM can be used to fabricate ceramic heat exchangers. However, the finish quality and accuracy of LOM are not as good as DMLS or SLM.

Additive manufacturing can help fabricate the complex and compact geometries of HTHXs which are otherwise almost impossible to fabricate. Several superalloys such as Inconel 718 and Inconel 625 are compatible with AM. It also allows fabrication of the heat exchanger as a single component, which eliminates the need to weld or braze different parts. There have been several successful attempts to fabricate HTHXs using AM, as summarized below.

\subsubsection{Manifold-microchannel Heat Exchanger}

The manifold-microchannel heat exchanger (M2HX) is a novel design that takes advantage of the high heat transfer rates of microchannels without the associated high pressure drops by reducing the flow length through the microchannel. However, a consequence of the short flow lengths is that the assumption of negligible spreading in the fluidseparating wall (base plate) may no longer be valid, and conventional heat exchanger correlations cannot be used to compute heat exchanger effectiveness. In the limiting case of extremely short flow lengths, spreading dominates, and a constant base plate temperature can be 
assumed. This is the approach taken by previous authors to determine heat exchanger effectiveness for a cross-flow M2HX currently under development for enhanced gas-to-gas heat transfer applications. In a manifold-microchannel heat exchanger, a manifold is placed on top of microchannels, as shown in Fig. 8(a). The inlet gas is then distributed into the microchannels through the manifold and travels a short length in each microchannel before it is guided out. The main advantages of the manifold-microchannel are, first, that the pressure drop in the manifoldmicrochannel heat exchanger can be reduced by a factor of the square of the number of divisions, due to the simultaneous reduction in both flow length and flow rate (Cetegen, 2010; Ohadi et al., 2013). Thus, for a given pressure drop, the manifold-microchannels allow smaller hydraulic diameters than would be possible with straight microchannels, resulting in higher heat transfer coefficients and reduced mass/volume ratio. Second, heat transfer coefficient is improved due to the short microchannel flow length, which causes thermally developing flow, which has higher heat transfer performance than fully developed flow. Third, the small fin size ( $<0.3 \mathrm{~mm}$ in width) allows for very high heat transfer surface area per volume ratio (1000 to $\left.2000 \mathrm{~m}^{2} / \mathrm{m}^{3}\right)$, which renders the manifold-microchannel heat exchangers more compact than most state-of-the-art heat exchangers. Finally, using the multi-pass manifold configuration as shown in Fig. 8(b), the effectiveness of M2HX can be increased by minimizing heat spreading in the wall separating the fluid streams.

It is challenging to fabricate manifold-microchannel heat exchanger structures using conventional fabrication techniques, as they consist of multiple manifold and microchannel layers stacked together. Due to the small size of the microchannels, improper brazing or welding between the manifold and microchannels can cause clogging in the microchannels resulting from a wicking effect. Metal additive manufacturing processes such as DMLS or SLM can be used to avoid this problem, as they fabricate parts layer by layer, allowing the manifold-microchannel to be fabricated as a single component and significantly simplifying the fabrication process.

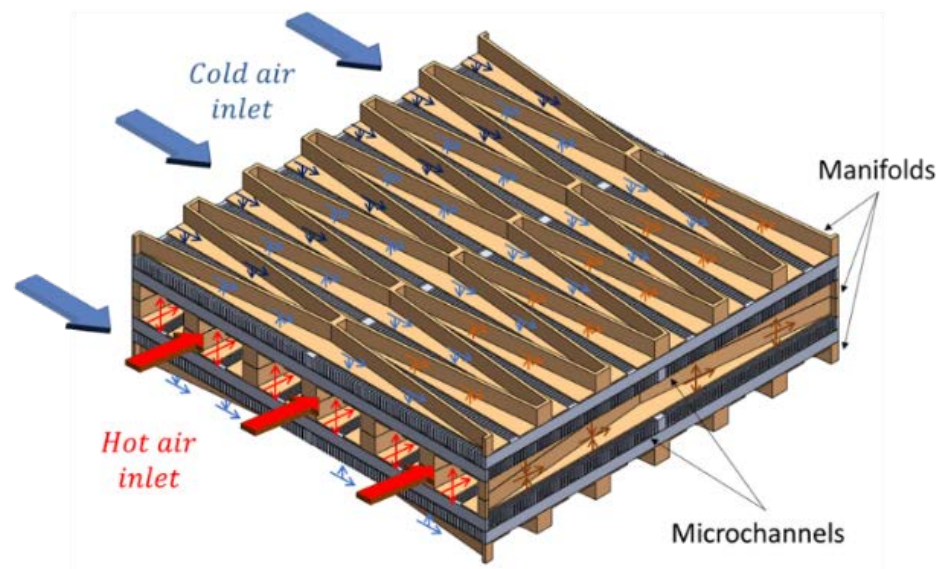

(a)

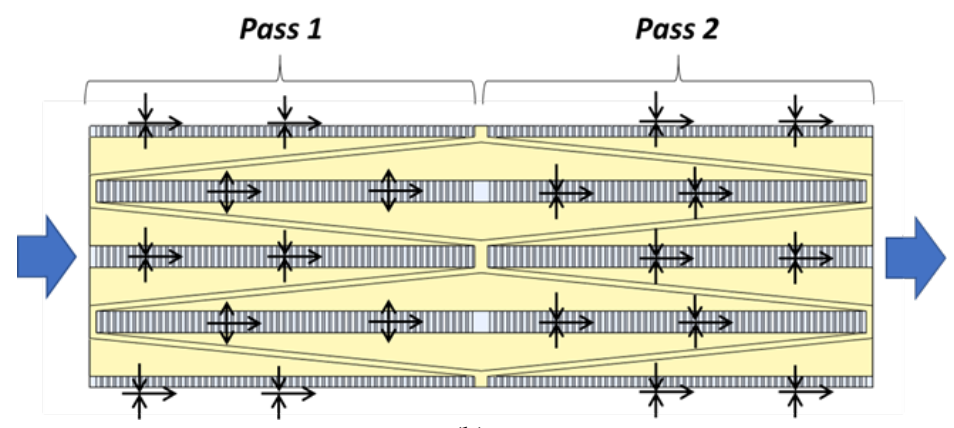

(b)

Fig. 8 Manifold-microchannel concept: (a) isometric view; (b) top view
Many studies have been reported in the literature that discuss the superior performance of this technology compared to conventional technologies in various applications (Arie et al., 2018; Arie et al., 2016; Ohadi et al., 2013). In those works, 50\% or higher heat transfer was reported for the same pressure drop when compared to state-of-the-art fins such as wavy fins, louver fins, and plain plate fins. A recent work at the Advanced Heat Exchangers and Process Intensification laboratory at University of Maryland (Zhang et al., 2018) shows that a manifoldmicrochannel heat exchanger fabricated using Inconel 718 can achieve $25 \%$ less weight for the same heat transfer and pressure drop performance compared to several commercially available PFHXs for pre-cooling applications at $600^{\circ} \mathrm{C}$ for aircraft applications, as shown in Fig. 9.

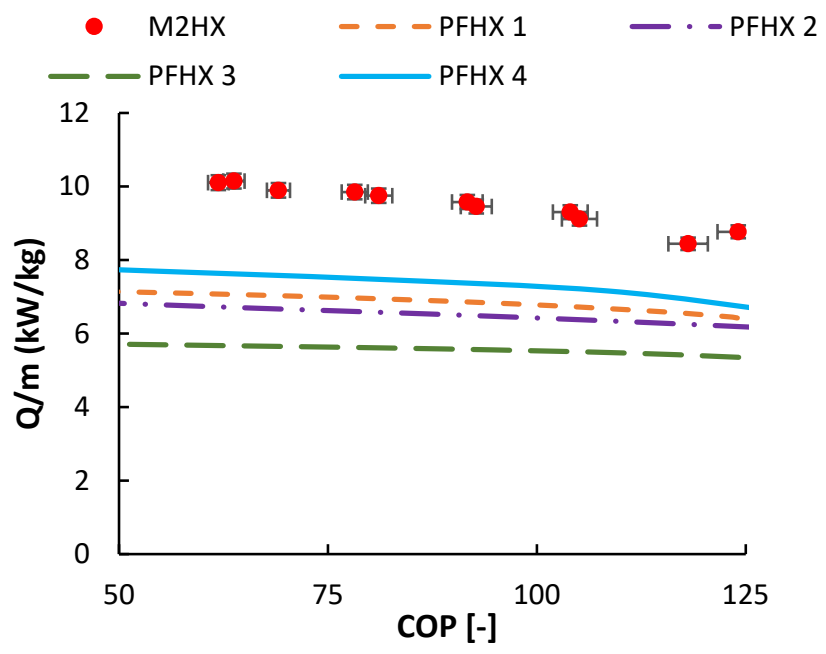

Fig. 9 Performance comparison between M2HX with plate-fin heat exchanger (PFHX)

\subsubsection{Multi-furcating Heat Exchanger}

Another type of 3D printed HTHX was developed by Gerstler and Erno (2017) from General Electric Global Research. They successfully fabricated multi-furcating heat exchangers using SLM for fuel-cooled oil cooler applications as shown in Fig. 10. The heat exchanger surfaces were fabricated using four different materials: aluminum, titanium alloy (Ti64), cobalt chrome, and Inconel 718. The test results showed that the heat exchangers met the pressure drop and heat transfer design requirement with $66 \%$ lower weight and $50 \%$ lower volume than the conventional heat exchangers.

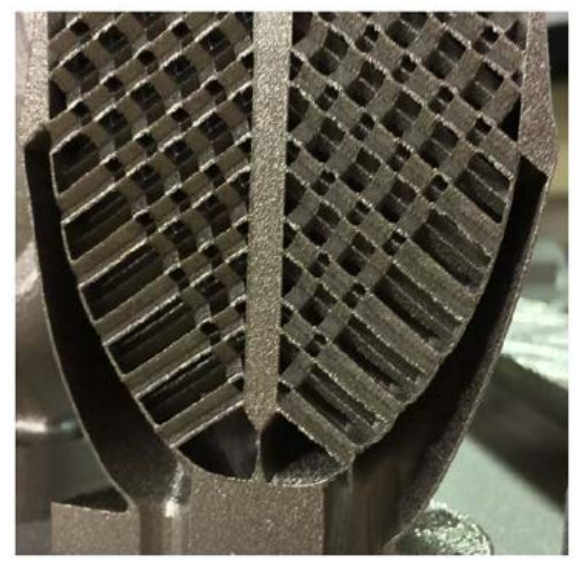

Fig. 10 Multi-furcating heat exchanger (Gerstler and Erno, 2017) (C) 2017 IEEE. Reprinted, with permission, from Introduction of An Additively Manufactured Multi-furcating Heat Exchanger, Gerstler, W. D. and Erno, D., 16th IEEE ITHERM Conference, 624-633, 2017. 


\subsubsection{Advanced Fin-and-tube Heat Exchanger}

In another study at University of Maryland, in collaboration with Oak Ridge National Laboratory (ORNL) (Leslie, 2016), a novel fin-and-tube heat exchanger was successfully fabricated out of titanium using DMLS. The heat exchanger has a complex fin geometry which cannot be economically fabricated using conventional manufacturing methods.

\subsection{Printed Circuit Heat Exchangers using Photo-chemical Etching}

Photo-chemical etching is a fabrication process that utilizes a photoresist and etchants to machine away a certain area of a metal plate. The process was initially developed for fabrication of printed circuit boards. However, due to its ability to etch various metals, including titanium, nickel superalloy, and copper superalloy, and its high accuracy, the process has been used to fabricate printed circuit heat exchangers.

The etching process is shown in Fig. 11. First, a photoresist layer is deposited on the metal surface. Then, the photoresist is exposed to UV light via a photo-tool. Afterward, the exposed metal is dissolved via an etching process to form semi-circular channels with typical channel width of 0.5-2 mm (Mylavarapu et al., 2012). Lastly, the photoresist is removed using a solution like alkaline. If the photo-tool specifies the area that needs to be dissolved by the UV light, the process is called positiveworking photoresist. If the photo-tool specifies the area that is left, the process is called negative-working photoresist.

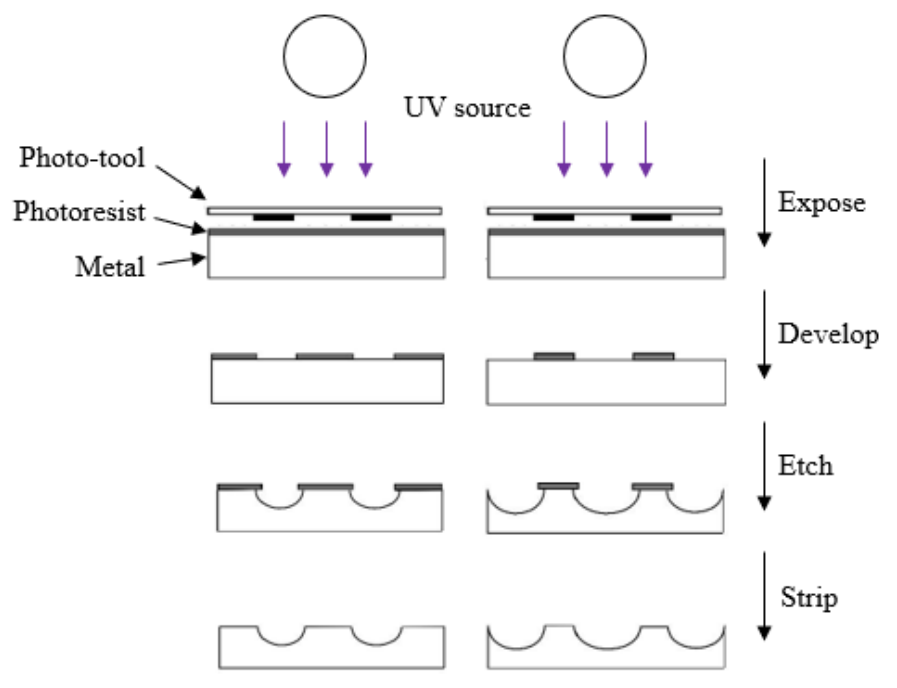

Negative photoresist Positive photoresist

Fig. 11 Photo-chemical etching process (adapted from reference (Eesa and Marriott, 2018))

Photo-chemical etching has been extensively used to fabricate printed circuit heat exchangers (PCHEs). The design consists of stacked plates with fine grooves etched into each plate as shown in Fig. 12. The stacked plates are usually bonded using a diffusion bonding technique. The common flow configurations of PCHE include counter-flow, crossflow, and cross-counter-flow. Some PCHEs are claimed to withstand a maximum design pressure of 900 bars and temperatures up to $980^{\circ} \mathrm{C}$ (Heatric, 2018). Heatric (2018) has successfully marketed a printed circuit heat exchanger fabricated using photo-chemical etching and diffusion bonding.

PCHEs achieve high thermal performance and are compact due to the smaller channel geometries. However, they incur larger pressure drops due to the long straight microchannels. The chemical etching process itself is expensive for the high temperature materials, as they are tough to etch. This makes these heat exchangers relatively expensive, especially for higher temperature applications. The low mass-based heat removal capability $(\mathrm{kW} / \mathrm{kg})$ and high cost of such heat exchangers has been a challenge for their adaptation in high temperature $\left(>600^{\circ} \mathrm{C}\right)$ and high pressure (>100 bar) applications.

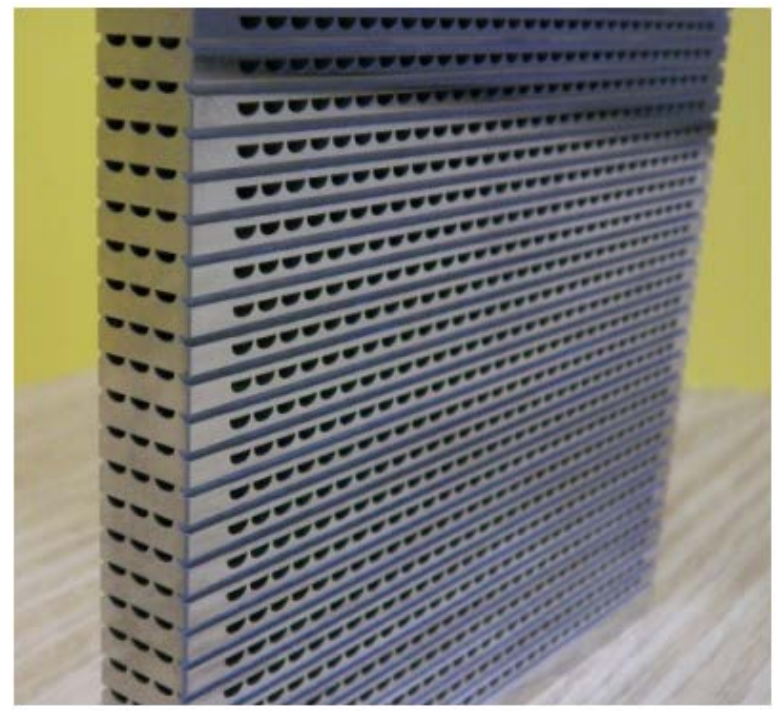

Fig. 12 Printed circuit heat exchanger (Shiferaw and Broad, 2014) Republished with permission of ASME 2014 Power Conference, from Diffusion Bonded Heat Exchangers (PCHEs) in Fuel Gas Heating to Improve Efficiency of CCGTs, Shiferaw, D. and Broad, R., Volume 1,2014; permission conveyed through Copyright Clearance Center, Inc.

\section{CERAMIC HEAT EXCHANGERS}

As discussed in the materials section, ceramic materials can be used for much higher temperatures than their metallic counterparts. Several different types of ceramic heat exchangers have been fabricated and tested, including ceramic PFHXs, plate and frame heat exchangers, and ceramic shell-and-tube heat exchangers (Ferrato and Thonon, 1997; Federzoni et al., 2007; Alm et al., 2005; Schmidt et al., 2011). Some of these heat exchangers can operate up to a peak temperature of $1370^{\circ} \mathrm{C}$ (Ferrato and Thonon, 1997).

Slip casting, tape casting, throwing, injection molding, and dry pressing are the common processes for fabrication of ceramic heat transfer surfaces. For example, injection molding was used by Fedarzoni et al. (Federzoni et al., 2007) to fabricate a plate-and-frame heat exchanger out of alumina with channel size of $0.5 \mathrm{~mm} \times 0.5 \mathrm{~mm}$. Similarly, shape molding (Schmidt et al., 2011) has been used to fabricate a plate-and-frame heat exchanger; slip casting has been used to fabricate a finned ceramic shell heat exchanger (Strumpf et al., 1982); and a combination of stereolithography and additive manufacturing technique with injection molding has been used to fabricate a plate-and-frame heat exchanger (Alm et al., 2005), all with features sizes as small as 250 microns.

Bonding of ceramic heat exchangers can be categorized into two categories: non-monolithic bond (non-permanent) and monolithic bond (permanent). A non-monolithic bond is a non-permanent bond whose structure can be easily de-bonded. Mechanical joints and seals are examples of non-monolithic bonds. A damaged heat exchanger fabricated using a non-permanent bond can be easily fixed by replacing the broken component. However, the bond is much weaker than monolithic bonds. Therefore, non-monolithic bonds are not suitable for high pressure heat exchanger applications. In addition, CTE mismatch is a problem for non-monolithic bonding between two different materials. On the other hand, a monolithic bond is a permanent bond whose structure cannot be de-bonded later. Monolithic bonds offer a stronger 
bond compared to non-monolithic bonds. Several examples of monolithic bonding techniques include polymer infiltration and pyrolysis (PIP), tape bonding, firing, and laser brazing.

PIP is the most common technique for bonding ceramic heat exchangers. The process involves deposition of low viscosity polymer between ceramic structures followed by pyrolysis. The pyrolysis is usually performed in an oxygen-free environment at temperatures of 800$1300^{\circ} \mathrm{C}$. This process has been successful in bonding ceramic heat exchangers (Peterson et al., 2006; Schmidt et al., 2011). These bonds were reported to tolerate pressure difference up to $9 \mathrm{MPa}$. Another technique for ceramic bonding is tape bonding. The process involves the use of sheets and ceramic powder as an interlayer bonding agent between the ceramic plates. Tape bonding is expected to provide a joint stronger than PIP. However, the process requires processing temperatures higher than PIP, which causes extensive creep on the heat exchanger. Lewinsohn et al. (Lewinsohn et al., 2012) showed that a heat exchanger fabricated using tape bonding had a higher shear strength than the one fabricated using PIP.

Ceramic heat exchangers have also been fabricated using AM. Ross et al. (Shulman and Ross, 2015) attempted to fabricate a compact 4 cubic inch ceramic heat exchanger out of zirconia-toughened mullite (ZTM) using the LOM process. Initial delamination of the layers during the fabrication was eliminated by decreasing the binder burnout rate and adding a tape cleaning step. The heat exchanger was successfully tested at $700^{\circ} \mathrm{C}$. Larger dimensions, however, were a challenge to fabricate due to the cracks caused by the defects. In another work by Alm et al. (Alm et al., 2005), a ceramic heat exchanger was fabricated using a combination of AM techniques (stereolithography) and injection molding. Additive manufacturing was used to create the injection molding mold. The use of AM allowed fabrication of the molds with feature size as small as $0.25 \mathrm{~mm}$, which showed the promise of AM in ceramic HTHX manufacturing.

\section{COMPARISON OF SELECTED HIGH TEMPERATURE HEAT EXCHANGERS}

Table 3 compares state-of-the art HTHXs. As seen there, for the listed heat exchangers, the shell-and-tube heat exchangers offer the highest maximum temperature and pressure. Shell-and-tube heat exchangers also benefit from being well researched and widely used in a diverse range of applications with good reliability. However, they are usually bulky and heavy due to their low heat transfer density. Plate-and-frame heat exchangers and plate-fin heat exchangers offer higher heat transfer density than shell-and-tube heat exchangers, although they need to operate at lower temperature and pressure. In addition, recent development of printed circuit heat exchangers has resulted in very compact heat exchangers with very high heat transfer density.

\section{EXAMPLES OF HIGH TEMPERATURE HEAT EXCHANGER DEMONSTRATIONS}

High temperature heat exchangers have several applications ranging from aerospace, waste heat recovery, nuclear heat utilization, exhaust gas recuperators, and as primary heaters and recuperators in advanced high efficiency power cycles such as supercritical $\mathrm{CO}_{2}$ Brayton cycle. The present section reviews some of the applications of the high power HTHXs currently being used or developed.

\subsection{Recuperator for Gas Turbine Power Generation}

For over half a century, gas turbines have been widely used in power plants and aircraft propulsion, in which heat exchangers have always played an important role. The heat exchanger serves as a recuperator, which preheats compressed air before it enters the combustor by recovering heat from exhaust gas. Thus, the gas turbine cycle efficiency can be increased and fuel consumption can be reduced (Franco and Casarosa, 2004). For this application, the typical compressor exit gas temperature can be as high as $725^{\circ} \mathrm{C}$, which requires an HTHX as the recuperator (Min et al., 2009). Three major types of recuperators in gas turbine systems are used: PFHXs, plate-and-frame heat exchangers, and shell-and-tube heat exchangers (Xiao et al., 2017).

Table 3 State-of-the-Art Heat Exchanger Comparison

\begin{tabular}{|l|l|l|l|l|}
\hline & $\begin{array}{l}A_{\text {heat }} / V \\
\left(\mathrm{~m}^{2} / \mathrm{m}^{3}\right)\end{array}$ & $\begin{array}{l}T_{\max } \\
\left({ }^{\circ} \mathrm{C}\right)\end{array}$ & $\begin{array}{l}\text { Pressure } \\
(\text { mar })\end{array}$ & Ref \\
\hline $\begin{array}{l}\text { Shell-and-tube } \\
\text { heat exchanger }\end{array}$ & $50-100$ & 1100 & 1000 & $\begin{array}{l}\text { (Shah and } \\
\text { Sekulic, 1998) }\end{array}$ \\
\hline $\begin{array}{l}\text { Plate-and-frame } \\
\text { heat exchanger }\end{array}$ & $120-660$ & 815 & 200 & $\begin{array}{l}\text { (Shah and } \\
\text { Sekulic, 1998) }\end{array}$ \\
\hline $\begin{array}{l}\text { Plate-fin heat } \\
\text { exchanger }\end{array}$ & $800-1500$ & 800 & 200 & $\begin{array}{l}\text { (Li } \text { et al., 2011; } \\
\text { Chordia } \text { et al., } \\
\text { 2017) }\end{array}$ \\
\hline $\begin{array}{l}\text { Printed circuit } \\
\text { heat exchanger }\end{array}$ & $200-2500$ & 980 & 900 & $\begin{array}{l}\text { (Heatric, 2018; } \\
\text { Chordia et al., } \\
\text { 2017) }\end{array}$ \\
\hline
\end{tabular}

For an optimized gas turbine cycle, whose inlet gas/air temperature is $825^{\circ} \mathrm{C} / 521^{\circ} \mathrm{C}$ and pressure ratio is 24.3 , Aquaro (2007) proposed a PFHX fabricated from superalloy with increased fin thickness of 0.15 $\mathrm{mm}$ on the air side to withstand the pressure at these maximum operating temperatures. Fig. 13 illustrates a PFHX designed by Toyo (Takase et al., 2002), which was used as a recuperator with effectiveness of about $90 \%$ in intercooled and recuperated micro gas turbines at about $650^{\circ} \mathrm{C}$ under inlet pressure about $400 \mathrm{kPa}$. Similar to the external shape of the PFHX design from Toyo, Ingersoll-Rand (Kesseli et al., 2003) also developed a plate-fin recuperator, which adopts offset fins in the heat transfer area, operates at $700^{\circ} \mathrm{C}$ with effectiveness of about $90 \%$, and has a cycle pressure ratio up to 14. AlliedSignal (Honeywell's predecessor) (Parker K, 1979; McDonald, 1996) produced a compact plate-fin ceramic recuperator for a cruise-missile propulsion application, and an industrial gas-turbine plate-fin recuperator (effectiveness of 84-89\%) with offset plate-fin surfaces which operates at $510-575^{\circ} \mathrm{C}$ and has a pressure ratio of 10 .

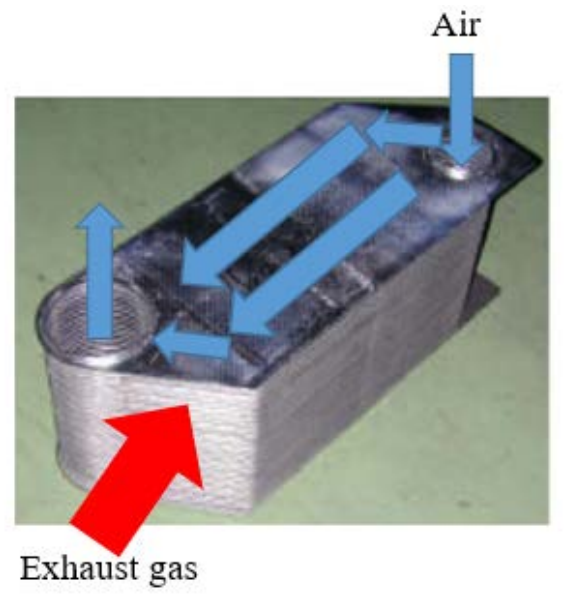

Fig. 13 PFHX recuperator designed by Toyo (adapted from reference (Takase et al., 2002))

Republished with permission of ASME Turbo Expo 2002, from A Preliminary Study of An Inter-cooled and Recuperative Microgasturbine Below 300 kW, Takase, K., Furukawa, H., and Nakano, K., Volume 1, 2002; permission conveyed through Copyright Clearance Center, Inc.

A plate-and-frame type recuperator with effectiveness of about $90 \%$ and operating temperature of $650^{\circ} \mathrm{C}$ has been developed by Rekuperator Svenska AB (RSAB) (Lagerström and Xie, 2002) for application in a micro gas turbine power plant for combined electricity and heat generation as shown in Fig. 14. Another welded plate-and-frame counter- 
flow recuperator developed by Honeywell (Muley and Sundén, 2003). A plate-and-frame recuperator with effectiveness of $90 \%$ was designed by Wilson et al. (2005) using silicon carbide, which improved the overall thermal efficiency from $27 \%$ to over $40 \%$, since the material can withstand inlet hot gas temperature of $955^{\circ} \mathrm{C}$.

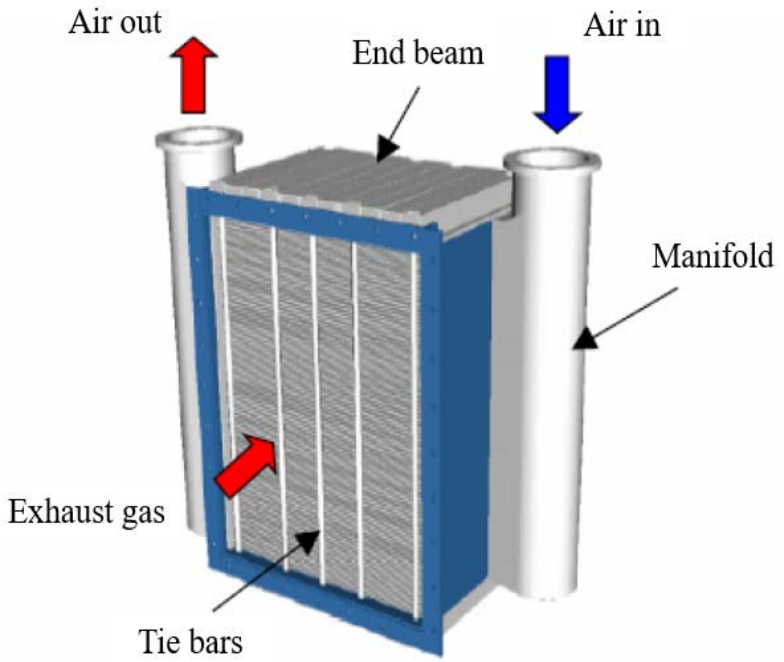

Fig. 14 Rectangular plate-and-frame recuperator by RSAB (Lagerström and Xie, 2002)

Republished with permission of ASME Turbo Expo 2002, from High Performance and Cost Effective Recuperator for MicroGas Turbines, Lagerström, G. and Xie, M., Volume 1, 2002; permission conveyed through Copyright Clearance Center, Inc.

Oak Ridge National Laboratory (Lara-Curzio et al., 2002) developed an annular plate-and-frame recuperator which can withstand inlet gas temperatures as high as $850^{\circ} \mathrm{C}$, inlet pressure of $690 \mathrm{kPa}$, and offers benefits from minimal ducting of the system (Fig. 15). Another counter-flow annular plate-and-frame recuperator with effectiveness of $90 \%$ and operating temperature of $725^{\circ} \mathrm{C}$ was designed by ACTE (Antoine and Prieels, 2002). Rolls-Royce (Oswald et al., 1999) also developed a spiral recuperator which operated with pressure ratio up to 14 and effectiveness up to $92 \%$.

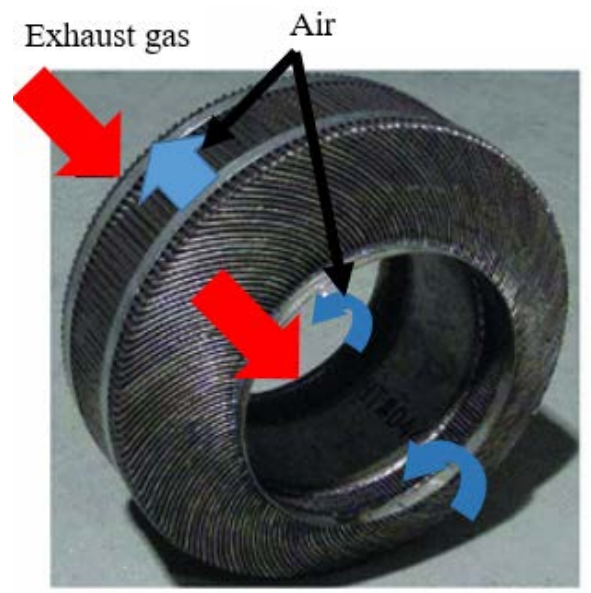

Fig. 15 Annular plate-and-frame recuperator designed by ORNL (adapted from reference (Treece et al., 2002))

Republished with permission of ASME Turbo Expo 2002, from Microturbine Recuperator Manufacturing and Operating Experience, Treece, B., Vessa, P., and McKeirnan, R., Volume 1, 2002; permission conveyed through Copyright Clearance Center, Inc.
In addition to plate-and-frame heat exchangers and PFHXs, shelland-tube heat exchangers are commonly used in gas turbine systems if size is not the limiting factor. Proe Power Systems (Proeschel, 2002) developed the Proe 90TM shell-and-tube recuperator, which operates with maximum temperature of $891^{\circ} \mathrm{C}$ and maximum inlet pressure of 621 $\mathrm{kPa}$, and has a predicted heat duty of $30 \mathrm{~kW}$, effectiveness of $95 \%$, and relatively low pressure drop (1-6 kPa). Schönenborn et al. (2004) also developed a cross-counter flow recuperator, shown in Fig. 16, which operates with maximum temperature of $671^{\circ} \mathrm{C}$ and maximum inlet pressure of $3091 \mathrm{kPa}$. This recuperator was fabricated with two manifold tubes and a bundle of profile tubes using Iconel 625. However, the estimated total weight of this shell-and-tube type recuperator was about $1,000 \mathrm{~kg}$ per engine, which clearly adds too much weight to the engine system on aircraft (Min et al., 2009).

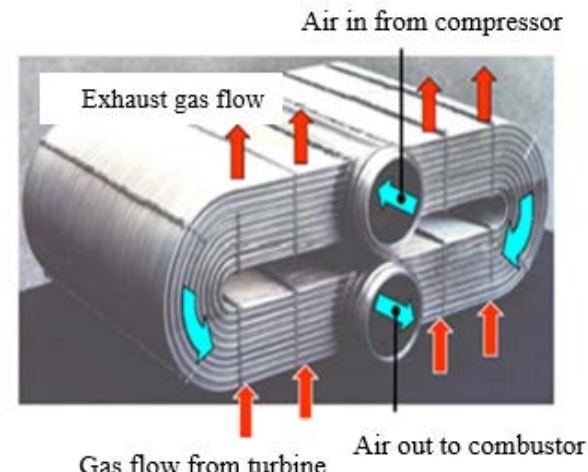

Fig. 16 Shell-and-tube recuperator (Boggia and Rüd, 2005)

(C) 2005 AIAA. Reprinted, with permission, from Intercooled Recuperated Gas Turbine Engine Concept, Boggia, S. and Rüd, K., 41st AIAA/ASME/SAE/ASEE Joint Propulsion Conference \& Exhibit, 2005

\subsection{Intermediate Heat Exchanger for Nuclear Heat Utilization}

Another application of HTHXs is nuclear heat utilization. For nuclear power plants, the heat exchangers must be both economically competitive and meet stringent safety requirements. Excellent safety characteristics can be achieved with high temperature gas-cooled reactors (HTGRs), since HTGRs have high heat capacity with their graphite core and high chemical stability with helium as the coolant (Aquaro and Pieve, 2007). However, to transfer the nuclear heat to the end user's facility, such as a hydrogen production or steam reforming system, a high temperature intermediate heat exchanger (IHX), which may use He as the working fluid on both sides and must operate above $900^{\circ} \mathrm{C}$, is needed (Crosbie and Chapin, 2003). In the 1980s, a shell-and-tube $\mathrm{He} / \mathrm{He}$ IHX was designed and constructed in Germany with a heat duty of $10 \mathrm{MW}$, which successfully ran some tests for several months up to $950^{\circ} \mathrm{C}$ (Cook et al., 1989; McDonald, 1996). Another $10 \mathrm{MW} \mathrm{He/He} \mathrm{IHX} \mathrm{based} \mathrm{on} \mathrm{the} \mathrm{shell-}$ and-tube design was designed in Japan to operate at temperatures above $900^{\circ} \mathrm{C}$ (Hada et al., 1991). The IHX is a vertical helically coiled counterflow heat exchanger. Primary He enters from the bottom at $950^{\circ} \mathrm{C}$ with inlet pressure of $4 \mathrm{MPa}$, while secondary He enters from top at $200^{\circ} \mathrm{C}$ with inlet pressure of $4.1 \mathrm{MPa}$. To minimize constraints of axial and radial thermal expansions on the tubes, a floating hot header with a combination of a central hot gas duct was adopted which passes through the central space inside the helix bundle.

\subsection{High Temperature Prime Heat Exchanger in Externally Fired Systems}

An externally fired combustion process takes place at atmospheric pressure outside the working fluid operating cycle. Generally, an externally fired system may have hot combustion temperatures of $1500^{\circ} \mathrm{C}$ and higher (Collings et al., 1999). Therefore, an HTHX is required to transfer heat from combustion to the gas turbine working fluid, which 
may have pressure up to 17 bar for a gas turbine or 250 bar or higher for a supercritical $\mathrm{CO}_{2}$ power generation cycle. As the heat exchanger has to withstand the stresses imposed by the working conditions and the constituents in the combustion gases, a shell-and-tube heat exchanger may generally be the preferred candidate for externally fired systems (Anheden, 2000).

One such HTHX is presented by K. A. Al-Attab (Al-attab and Zainal, 2010), as shown in Fig. 17. In this biomass fuel powered system, a twopass cross-flow heat exchanger with baffle shells and tubes was chosen to transfer the combustion heat to the compressed air. Due to the selected material, stainless steel, the maximum turbine inlet temperature was limited to $694^{\circ} \mathrm{C}$. If a nickel-based superalloy had been used for the heat exchanger's fabrication, a maximum turbine inlet temperature of 800$825^{\circ} \mathrm{C}$ may have been reached (Anheden, 2000).

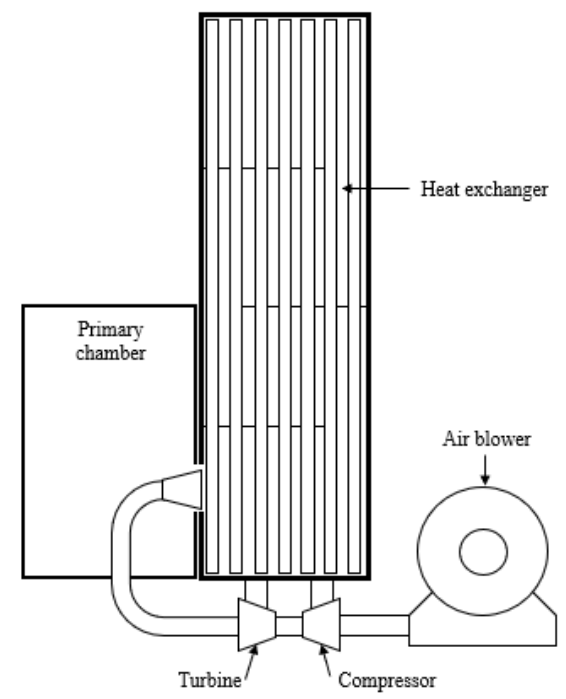

Fig. 17 A biomass fuel powered externally fired system (adapted from reference (Al-attab and Zainal, 2010))

\subsection{Pre-Cooler for Aircraft Environmental Control System Applications}

The environmental control system is used in aircrafts to maintain a comfortable closed environment by keeping temperature within acceptable limits. Hot bleed air from the engine compressor, which has temperature of 500 to $750^{\circ} \mathrm{C}$ is precooled using HTHX, so that it can circulate within the various systems of the aircraft for other usage (Martinez, 2018; Bombardier Inc., 2012; Tsuji, 2003). The pre-coolers are typically compact PFHXs that have relatively high heat transfer surface area per volume ratios. Since weight is a critical design point for components on aircraft, a plate-fin carbon-carbon heat exchanger operating at $650^{\circ} \mathrm{C}$ was designed by Stevenson et al. (1999). This HTHX achieved about $40 \%$ mass reduction over a common metallic HTHX. However, multi-component coatings were needed for this carbon-carbon heat exchanger to avoid the oxidation issue at this operating temperature. Most recently, a manifold-microchannel high temperature pre-cooler heat exchanger was developed and tested at the Advanced Heat Exchanger laboratory at the University of Maryland (Zhang et al., 2015). The precooler core with a size of about $7.5 \mathrm{~cm} \times 7.5 \mathrm{~cm} \times 2.5 \mathrm{~cm}$ was fabricated with DMLS using Inconel 718 as shown in Fig. 18(a). The flow inlet and outlet manifolds were also fabricated by AM and welded to the pre-cooler core. This 3D printed manifold-microchannel pre-cooler was tested at $600^{\circ} \mathrm{C}$ and an inlet pressure of $448 \mathrm{kPa}$. The test results demonstrated an overall heat transfer coefficient up to $1000 \mathrm{~W} / \mathrm{m}^{2} \mathrm{~K}$ for gas-to-gas application, and a heat transfer density of $\sim 10 \mathrm{~kW} / \mathrm{kg}$, which is $25 \%$ higher than typical PFHXs (Zhang et al., 2018). Moreover, a larger $10 \mathrm{~cm} \times 10 \mathrm{~cm} \times 10 \mathrm{~cm}$ M2HX has also been successfully fabricated as shown in Fig. 18(b).

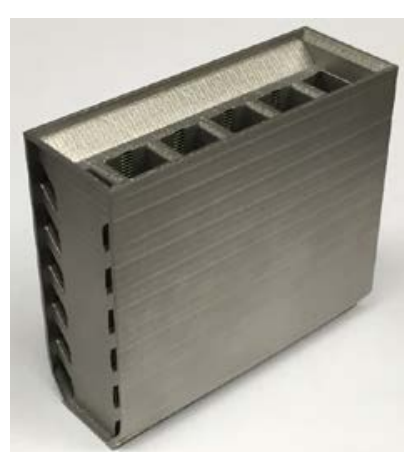

(a)

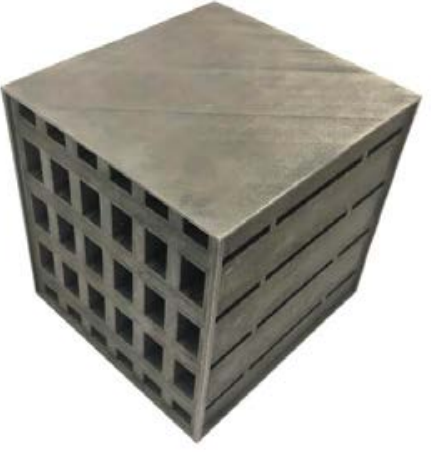

(b)
Fig. 18 Additively manufactured M2HX fabricated using Inconel 718: (a) Gen 1 (2 kW capacity); (b) Gen 2 (10 kW capacity)

\subsection{High Temperature Industrial Waste Heat Recovery}

Industrial waste heat refers to the energy generated as a byproduct in industrial processes that otherwise is not put to useful practical use. Examples of high temperature waste heat sources with temperatures of more than $500^{\circ} \mathrm{C}$ include metal refining/heating furnaces, hydrogen plants, and glass melting furnaces. For example, exhaust gases leaving the reverberatory furnace, which are frequently used in aluminum melting operations, usually have temperatures from 600 to $1300^{\circ} \mathrm{C}$, and $40-60 \%$ of furnace energy input can be carried way with these exhaust gases. HTHXs can be utilized to recover most or a good portion of this waste heat and improve the total cycle efficiency.

\section{CONCLUSIONS}

Cost effective high temperature heat exchangers are key to the success of emerging high-temperature, high-efficiency modular power cycles for diverse applications of energy conversion, power generation and energy/waste heat recovery applications. Most common heat exchangers currently available in the market are the plate-fin, plate-and-frame, and shell-and-tube types. The ideal high temperature heat exchanger would offer an optimum balance among heat transfer effectiveness, pressure drop, size and weight (indirectly controlling the cost) of the heat exchanger, while meeting longevity and reliability requirements. For elevated temperatures, most heat-resistant superalloys that can withstand the required temperature suffer from low thermal conductivity and high cost. Therefore, innovative design, materials, and manufacturing techniques are crucial to successful development of such heat exchangers. While additive manufacturing of superalloys for high temperature applications faces numerous challenges, it is believed that additional research support in this field can overcome many of the challenges. Significant progress has already been made in the past few years and demonstrates the promise of AM for fabrication of high temperature heat exchangers. Some recent work has employed a hybrid approach, a combination of AM and non-AM manufacturing solutions. Such approach may be a practical choice for certain applications. Investment of research funds in a new generation of AM machines may be timely to overcome some of their current limitations (e.g., limited build volume) and facilitate printer parameter optimization and quality of the finished product. Other research opportunities include the development of a feedback loop control for the printers to ensure the quality control of the print. Similarly, the materials for additively manufactured parts for high temperature applications require significant research and development. For example, utilization of select high temperature and high pressure Haynes alloys may be a useful step toward next-generation HTHXs. Furthermore, ceramic material with two-dimensional reinforcement could be used for HTHXs to improve the mechanical properties and increase the pressure that ceramic heat exchangers can withstand. 


\section{NOMENCLATURE}

$\begin{array}{ll}\text { AM } & \text { Additive manufacturing } \\ \text { CMC } & \text { Ceramic matrix composites } \\ \text { CTE } & \text { Coefficient of thermal expansion } \\ \text { DMLS } & \text { Direct metal laser sintering } \\ \text { EBM } & \text { Electron beam melting } \\ \text { HTGR } & \text { High temperature gas-cooled reactor } \\ \text { HTHX } & \text { High temperature heat exchanger } \\ \text { IHX } & \text { Intermediate heat exchanger } \\ \text { LOM } & \text { Laminated object manufacturing } \\ \text { M2HX } & \text { Manifold-microchannel heat exchanger } \\ \text { LTHX } & \text { Low temperature heat exchanger } \\ \text { PCHX } & \text { Printed circuit heat exchanger } \\ \text { PFHX } & \text { Plate-fin heat exchanger } \\ \text { PIP } & \text { Polymer infiltration and pyrolysis } \\ \text { SLM } & \text { Selective laser melting } \\ \text { SCO2 } & \text { Super critical CO } \text { CO }_{2}\end{array}$

\section{REFERENCES}

Al-attab, K. A., and Zainal, Z. A., 2010, "Performance of Hightemperature Heat Exchangers in Biomass Fuel Powered Externally Fired Gas Turbine Systems," Renewable Energy, 35(5): 913-920. https://doi.org/10.1016/j.renene.2009.11.038

Alm, B., Knitter, R., and Hausselt, J., 2005, "Development of A Ceramic Micro Heat Exchanger-Design, Construction, And Testing," Chemical engineering \& technology, 28(12): 1554-1560.

https://doi.org/10.1002/ceat.200500253

American Iron and Steel Institute, "High Temperature Characteristics of Stainless Steels," Nickel Development Institute,

https://www.nickelinstitute.org/ /Media/Files/TechnicalLiterature/High _TemperatureCharacteristicsofStainlessSteel_9004_pdf (accessed May 30, 2018).

Anheden, M., 2000, "Analysis of Gas Turbine Systems for Sustainable Energy Conversion," $\mathrm{PhD}$ thesis, Royal Institute of Technology, Stockholm, Sweden.

Antoine, H., and Prieels, L., 2002, "The ACTE Spiral Recuperator for Gas Turbine Engines," ASME Turbo Expo 2002: Power for Land, Sea, and Air, 1025-1031. Amsterdam, The Netherlands.

https://doi.org/10.1115/GT2002-30405

Aquaro, D., and Pieve, M., 2007, "High Temperature Heat Exchangers for Power Plants: Performance of Advanced Metallic Recuperators," Applied Thermal Engineering, 27: 389-400.

https://doi.org/10.1016/j.applthermaleng.2006.07.030

Arie, M. A., Shooshtari, A. H., and Ohadi, M. M., 2018, "Experimental Characterization of An Additively Manufactured Heat Exchanger for Dry Cooling of Power Plants," Applied Thermal Engineering, 129: 187-198. https://doi.org/10.1016/j.applthermaleng.2017.09.140

Arie, M. A., Shooshtari, A. H., Rao, V. V., Dessiatoun, S. V., and Ohadi, M. M., 2016, "Air-Side Heat Transfer Enhancement Utilizing Design Optimization and An Additive Manufacturing Technique," Journal of Heat Transfer, 139.

https://doi.org/10.1115/1.4035068

Arie, M. A., Shooshtari, A. H., Tiwari, R., Dessiatoun, S. V., Ohadi, M. M., and Pearce, J. M., 2017, "Experimental Characterization of Heat
Transfer in An Additively Manufactured Polymer Heat Exchanger," Applied Thermal Engineering, 113: 575-584.

https://doi.org/10.1016/j.applthermaleng.2016.11.030

Arie., M. A., 2016, "Air-side Heat Transfer Enhancement in Heat Exchanger Utilizing Innovative Designs and Additive Manufacturing Technique", PhD thesis, University of Maryland, College Park.

AZO Materials, 2018, "Materials Science Articles,"

https://www.azom.com/articles.aspx (accessed May 14, 2018).

Boggia, S., and Rüd, K., 2005, "Intercooled Recuperated Gas Turbine Engine Concept," 41st AIAA/ASME/SAE/ASEE Joint Propulsion Conference \& Exhibit, 4192, Tucson, Arizona.

https://doi.org/10.2514/6.2005-4192

ASME Boiler and Pressure Vessel and Process Piping Code, 2010, "Section VIII Division 1," UG-126 Pressure Relief Valves to UG-129 Marking, ASME International, New York.

Bombardier Inc., 2012, "System and Method for Operating A Precooler in An Aircraft," https://patents.justia.com/patent/9624831 (accessed May 30, 2018).

Brun, K., Friedman, P., and Dennis, R., 2017, Fundamentals and Applications of Supercritical Carbon Dioxide (sCO2) Based Power Cycles, Woodhead Publishing, Cambridge, Massachusetts.

Cetegen, E., 2010, "Force Fed Microchannel High Heat Flux Cooling Utilizing Microgrooved Surfaces," PhD thesis, University of Maryland, College Park.

Chordia, L., Portnoff, M. A., and Green, E., 2017, "High Temperature Heat Exchanger Design and Fabrication for Systems with Large Pressure Differentials," Thar Energy LLC, Pittsburgh, Pennsylvania (United States).

https://doi.org/10.2172/1349235

Collings, M. E., Dockter, B. A., Hajicek, D. R., Henderson, A. K., Hurley, J. P., Kleven, P. L., and Weber, G. F., 1999, "High-temperature Heat Exchanger Testing in A Pilot-Scale Slagging Furnace System," University of North Dakota (United States).

https://doi.org/10.2172/824978

Continental Steel \& Tube Company, 2015, "Considerations when Machining Nickel Alloys,

"https://continentalsteel.com/blog/considerations-when-machiningnickel-alloys/ (accessed March 31, 2018).

Cook, R., Exner, R., and Graham, L., 1989, "Post-service Examination of A 10 MW Helium-helium Heat Exchanger and Comparison with Long Term Behaviour in Laboratory Tests," High Temperature Metallic Materials for Gas-Cooled Reactors: 129.

Crosbie, L. M., and Chapin, D., 2003, "Hydrogen Production by Nuclear Heat," GENES4/ANP2003, International Conference on Global Environment and Advanced Nuclear Power Plants, Kyoto, Japan

Stevenson, R. D., D. L. Vrable, and R. J. Watts., 1999, "Development of An Intermediate Temperature Carbon-Carbon Heat Exchanger for Aircraft Applications," Society for the Advancement of Material and Process Engineering, Evolving and Revolutionary Technologies for the New Millenium, 44, 1888-1897. 
David, S. A., Siefert, J. A., DuPont, J. N., and Shingledecker, J. P., 2015, "Weldability and Weld Performance of Candidate Nickel Base Superalloys for Advanced Ultrasupercritical Fossil Power Plants Part I: Fundamentals," Science and Technology of Welding and Joining, 20: 532-552.

https://doi.org/10.1179/1362171815Y.0000000035

Federzoni, L., Gruss, J.-A., and Brochard, J.-A., 2007, "Heat Exchanger Manufactured by Ceramic Injection Moulding," 18ème Congrès Français de Mécanique, Grenoble.

Ferrato, M., and Thonon, B., 1997, "A Compact Ceramic Plate-Fin Heat Exchanger for Gas Turbine Heat Recovery," Conference in Snowbird, Utah, USA.

Foerster, S., and Kleemann, M., 1978, "Compact Metallic and Ceramic Recuperators for Gas Turbines," ASME 1978 International Gas Turbine Conference and Products Show, American Society of Mechanical Engineers, London, England.

https://doi.org/10.1115/78-GT-62

Franco, A., and Casarosa, C., 2004, "Thermoeconomic Evaluation of The Feasibility of Highly Efficient Combined Cycle Power Plants," Energy, 29: 1963-1982.

https://doi.org/10.1016/j.energy.2004.03.047

Gerstler, W. D., and Erno, D., 2017, "Introduction of An Additively Manufactured Multi-Furcating Heat Exchanger," Thermal and Thermomechanical Phenomena in Electronic Systems (ITherm), 16th IEEE Intersociety Conference, 624-633, Orlando, FL.

https://doi.org/10.1109/ITHERM.2017.7992545

Hada, K., Nishiguchi, I., Muto, Y., and Tsuji, H., 1991, "Developments of Metallic Materials and A High-Temperature Structural Design Code for The HTTR," Nuclear Engineering and Design, 132: 1-11. https://doi.org/10.1016/0029-5493(91)90289-T

Heatric, 2018, "The Exceptional Performance of Heatric PCHE Heat Exchangers,"https://www.heatric.com/heat_exchanger_performance.ht ml (accessed March 31, 2018).

Heatric, 2018, "Typical Characteristics of Diffusion-bonded Heat Exchangers,"https://www.heatric.com/typical_characteristics_of_PCHE s.html (accessed March 31, 2018).

Johnson, I., Choate, W. T., and Davidson, A., 2008, "Waste Heat Recovery. Technology and Opportunities in US Industry," BCS Inc., Laurel, MD (United States).

https://doi.org/10.2172/1218716

Kandlikar, S., Garimella, S., Li, D., Colin, S., and King, M. R., 2005, Heat Transfer and Fluid Flow in Minichannels and Microchannels, Elsevier. Waltham, Massachusett.

https://doi.org/10.1016/B978-0-08-044527-4.X5000-2

Kesseli, J., Wolf, T., Nash, J., and Freedman, S., 2003, "Micro, Industrial, and Advanced Gas Turbines Employing Recuperators," ASME Turbo Expo 2003, collocated with the 2003 International Joint Power Generation Conference, 789-794. American Society of Mechanical Engineers, Atlanta, Georgia, USA.

https://doi.org/10.1115/GT2003-38938

Krenkel, W., and Berndt, F., 2005, "C/C-SiC Composites for Space Applications and Advanced Friction Systems," Materials Science and Engineering: A, 412: 177-181. https://doi.org/10.1016/j.msea.2005.08.204

Lagerström, G., and Xie, M., 2002, "High Performance and Cost Effective Recuperator for Micro-Gas Turbines," ASME Turbo Expo 2002: Power for Land, Sea, and Air, 1003-1007, Amsterdam, The Netherlands. https://doi.org/10.1115/GT2002-30402

Lara-Curzio, E., Maziasz, P. J., Pint, B. A., Stewart, M., Hamrin, D., Lipovich, N., and DeMore, D., 2002, "Test Facility for Screening and Evaluating Candidate Materials for Advanced Microturbine Recuperators," ASME Turbo Expo 2002: Power for Land, Sea, and Air, 1135-1141, Amsterdam, The Netherlands.

https://doi.org/10.1115/GT2002-30581

Leslie, L., 2016, "Metal Additive Manufacturing Enables Lean, Green Heat Exchanger," http://www.makepartsfast.com/metal-additivemanufacturing-enables-lean-green-heat-exchanger/ (accessed March 31, 2018).

Lewinsohn, C. A., Wilson, M. A., Fellows, J. R., and Anderson, H. S., 2012, "Fabrication and Joining of Ceramic Compact Heat Exchangers for Process Integration," International Journal of Applied Ceramic Technology, 9: 700-11.

https://doi.org/10.1111/j.1744-7402.2012.02788.x

Li, Q., Flamant, G., Yuan, X., Neveu, P., and Luo, L., 2011, "Compact Heat Exchangers: A Review and Future Applications for A New Generation of High Temperature Solar Receivers," Renewable and Sustainable Energy Reviews, 15: 4855-75.

https://doi.org/10.1016/j.rser.2011.07.066

Lippmann, W., Knorr, J., Wolf, R., Rasper, R., Exner, H., Reinecke, A.M., Nieher, M., and Schreiber, R., 2004, "Laser Joining of Silicon Carbide-A New Technology for Ultra-high Temperature Resistant Joints," Nuclear Engineering and Design, 231: 151-61.

https://doi.org/10.1016/j.nucengdes.2004.03.002

Luzzatto, C., Morgana, A., Chaudourne, S., O'Doherty, T., and Sorbie, G., 1997, "A New Concept Composite Heat Exchanger to be Applied in High-Temperature Industrial Processes," Applied Thermal Engineering, 17: 789-97.

https://doi.org/10.1016/S1359-4311(96)00060-9

Eesa M., and Marriott G., 2018, "Photochemical Etching of Heat Exchanger Plates,

"http://www.heatexdesign.com/_resources/assets/attachment/full/0/3017 205.pdf (accessed March 31, 2018).

Magistri, L., Traverso, A., Massardo, A., and Shah, R., 2006, "Heat Exchangers for Fuel Cell and Hybrid System Applications," Journal of fuel cell science and technology, 3: 111-18.

https://doi.org/10.1115/1.2173665

Magrab, E. B., Gupta, S. K., McCluskey, F. P., and Sandborn, P., 2009, Integrated product and process design and development: the product realization process, CRC Press, Boca Raton, Florida.

Mansilla, C., Sigurvinsson, J., Bontemps, A., Maréchal, A., and Werkoff, F., 2007, "Heat Management for Hydrogen Production by High Temperature Steam Electrolysis," Energy, 32: 423-430.

https://doi.org/10.1016/j.energy.2006.07.033

Marlin Steel, 2016, "4 Inconel Machining Tips You Need to Know," https://www.marlinwire.com/blog/inconel-machining-tips (accessed March 31, 2018). 
Martinez, I., 2018, "Aircraft Environmental Control," http://webserver.dmt.upm.es/ WoSdoro/tc3/Aircraft\%20ECS.pdf (accessed March 31, 2018).

Maziasz, P. J., Pint, B. A., Shingledecker, J. P., Evans, N. D., Yamamoto, Y., More, K. L., and Lara-Curzio, E., 2007, "Advanced Alloys for Compact, High-efficiency, High-temperature Heat-exchangers," International Journal of Hydrogen Energy, 32: 3622-30.

https://doi.org/10.1016/j.ijhydene.2006.08.018

Maziasz, P. J., and Swindeman, R. W., 2003, "Selecting and Developing Advanced Alloys for Creep-resistance for Microturbine Recuperator Applications," Journal of Engineering for Gas Turbines and Power, 125: 310-315.

https://doi.org/10.1115/1.1499729

McDonald, C. F., 1980, "The Role of The Ceramic Heat Exchanger in Energy and Resource Conservation," Journal of Engineering for Power, 102(2): 303-315.

https://doi.org/10.1115/1.3230253

McDonald, C. F., 1996, "Compact Buffer Zone Plate-fin IHX-The Key Component for High-Temperature Nuclear Process Heat Realization with Advanced MHR," Applied Thermal Engineering, 16: 3-32.

https://doi.org/10.1016/1359-4311(95)00016-7

McDonald, C. F., 2000, "Low-cost compact Primary Surface Recuperator Concept for Microturbines," Applied Thermal Engineering, 20: 471-497. https://doi.org/10.1016/S1359-4311(99)00033-2

McDonald, C. F., 2003, "Recuperator Considerations for Future Higher Efficiency Microturbines", Applied Thermal Engineering, 23: 1463-1487. https://doi.org/10.1016/S1359-4311(03)00083-8

Min, J. K., Jeong, J. H., Ha, M. Y., and Kim, K. S., 2009, "High Temperature Heat Exchanger Studies for Applications to Gas Turbines," Heat and Mass Transfer, 46: 175-86.

https://doi.org/10.1007/s00231-009-0560-3

Mori, Y., Sheĭndlin, A. E., and Afgan, N. H., 1986, High Temperature Heat Exchangers, Hemisphere Pub. Corp., Washington, D.C.

Muley, A., and Sundén, B., 2003, "Advances in Recuperator Technology for Gas Turbine Systems," ASME 2003 International Mechanical Engineering Congress and Exposition, 161-169, American Society of Mechanical Engineers, Washington, DC, USA.

https://doi.org/10.1115/IMECE2003-43294

Musgrove, G., LePierres, R., and Nash J., 2014, "Heat Exchangers for Supercritical CO2 Power Cycle Applications," In The 4th International Symposium on Supercritical CO2 Power Cycles, Pittsburgh PA.

Mylavarapu, S. K., Sun, X., Christensen, R. N., Unocic, R. R., Glosup, R. E., and Patterson, M. W., 2012, "Fabrication and Design Aspects of High-temperature Compact Diffusion Bonded Heat Exchangers," Nuclear Engineering and Design, 249: 49-56.

https://doi.org/10.1016/j.nucengdes.2011.08.043

Nielsen, R., 2000, "Zirconium and Zirconium Compounds," Ullmann's Encyclopedia of Industrial Chemistry.

https://doi.org/10.1002/14356007.a28_543

Nikulin, I., Kaibyshev, R., and Skorobogatykh, V., 2010, "High Temperature Properties of An Austenitic Stainless Steel," Journal of Physics: Conference Series, 240: 012071, IOP Publishing. https://doi.org/10.1088/1742-6596/240/1/012071

Ohadi, M., Choo, K., Dessiatoun, S., and Cetegen, E., 2013, Next Generation Microchannel Heat Exchangers, Springer, New York. https://doi.org/10.1007/978-1-4614-0779-9

Ohadi, M. M., and Buckley, S. G., 2001, "High Temperature Heat Exchangers and Microscale Combustion Systems: Applications to Thermal System Miniaturization," Experimental Thermal and Fluid Science, 25: 207-17.

https://doi.org/10.1016/S0894-1777(01)00069-3

Oswald, J. I., Dawson, D. A., and Clawley, L. A., 1999, "A New Durable Gas Turbine Recuperator," ASME 1999 International Gas Turbine and Aeroengine Congress and Exhibition. American Society of Mechanical Engineers, Indianapolis, Indiana, USA.

https://doi.org/10.1115/99-GT-369

Panel, E. N., 2014, "Scientific Opinion on Dietary Reference Values for chromium," EFSA Journal, 12: 25.

https://doi.org/10.2903/j.efsa.2014.3845

Parker K, C. M., 1979, "Development in Plate-fin Heat Exchangers," ASME Publication HTD, 10: 171-79.

Peterson, P. F., Zhao, H., Niu, F., Wang, W., Schmidt, J., and SchulteFischedick, J., 2006, "Development of C-SiC Ceramic Compact Plate Heat Exchangers for High Temperature Heat Transfer Applications," In AICHE Annual Meeting.

Pint, B. A., and Keiser, J. R., 2016, "The Effect of Temperature and Pressure on Supercritical CO2 Compatibility of Conventional Structural Alloys," Oak Ridge National Laboratory (ORNL), Oak Ridge, Tennessee, USA.

Proeschel, R. A., 2002, "Proe 90 ${ }^{\mathrm{TM}}$ Recuperator for Microturbine Applications," ASME Turbo Expo 2002: Power for Land, Sea, and Air, 1033-44. American Society of Mechanical Engineers, Amsterdam, Netherlands.

https://doi.org/10.1115/GT2002-30406

Rohde, M., Südmeyer, I., Urbanek, A., and Torge, M., 2009, "Joining of Alumina and Steel by A Laser Supported Brazing Process," Ceramics International, 35: 333-337.

https://doi.org/10.1016/j.ceramint.2007.11.007

Schmidt, J., Scheiffele, M., Crippa, M., Peterson, P. F., Urquiza, E., Sridharan, K., Olson, L. C., Anderson, M. H., Allen, T. R., and Chen, Y., 2011, "Design, Fabrication, and Testing of Ceramic Plate-Type Heat Exchangers with Integrated Flow Channel Design," International Journal of Applied Ceramic Technology, 8: 1073-1086.

https://doi.org/10.1111/j.1744-7402.2010.02573.x

Schmitt, C., Agar, D. W., Platte, F., Buijssen, S., Pawlowski, B., and Duisberg, M., 2005, "Ceramic Plate Heat Exchanger for Heterogeneous Gas Phase Reactions," Chemical engineering \& technology, 28: 337-343. https://doi.org/10.1002/ceat.200407119

Schönenborn, H., Ebert, E., Simon, B., and Storm, P., 2004, "Thermomechanical Design of A Heat Exchanger for A Recuperative Aero Engine," ASME Turbo Expo 2004: Power for Land, Sea, and Air, 187-93. American Society of Mechanical Engineers, Vienna, Austria.

https://doi.org/10.1115/GT2004-53696 
Schulte-Fischedick, J., Dreißigacker, V., and Tamme, R., 2007, "An Innovative Ceramic High Temperature Plate-fin Heat Exchanger for EFCC Processes," Applied Thermal Engineering, 27: 1285-1294.

https://doi.org/10.1016/j.applthermaleng.2006.11.007

Seo, J. W., Cho, C., Lee, S., and Choi, Y. D., 2015, "Thermal Characteristics of A Primary Surface Heat Exchanger with Corrugated Channels," Entropy, 18.

https://doi.org/10.3390/e18010015

Shah, R., and Sekulic, D., 1998, 'Heat Exchangers,' in Warren M. Rohsenow, James P. Hartnett and Young I. Cho (eds.), Handbook of Heat Transfer, McGraw-Hill, New York.

Shiferaw, D., and Broad, R., 2014, "Diffusion Bonded Heat Exchangers (PCHEs) in Fuel Gas Heating to Improve Efficiency of CCGTs," ASME 2014 Power Conference, American Society of Mechanical Engineers, Baltimore, Maryland, USA.

https://doi.org/10.1115/POWER2014-32008

Shulman, H., and Ross, N., 2015, "Additive Manufacturing for Cost Efficient Production of Compact Ceramic Heat Exchangers and Recuperators," Ceralink Inc. and United Technologies Research Center. https://doi.org/10.2172/1234436

Smyth, R., 1997, "A Proposal for The Use of A Very High Temperature Ceramic Heat Exchanger in Gas Turbine Power Production," Energy Conversion Engineering Conference, IECEC-97., Proceedings of the 32nd Intersociety, 1696-1701. IEEE, Honolulu, Hawaii, USA.

https://doi.org/10.1109/IECEC.1997.656677

Sommers, A., Wang, Q., Han, X., T'Joen, C., Park, Y., and Jacobi, A., 2010, "Ceramics and Ceramic Matrix Composites for Heat Exchangers in Advanced Thermal Systems-A Review," Applied Thermal Engineering, 30: 1277-1291.

https://doi.org/10.1016/j.applthermaleng.2010.02.018

Special Metals, 2012, "High-Performance Alloys,"

https://archive.is/20121208171938/http://www.specialmetals.com/produ cts/index.php (accessed March 31, 2018).

Stasiek, J., 1998, "Experimental Studies of Heat Transfer and Fluid Flow Across Corrugated-undulated Heat Exchanger Surfaces," International Journal of Heat and Mass Transfer, 41: 899-914.

https://doi.org/10.1016/S0017-9310(97)00168-3

Strumpf, H. J., Kotchick, D. M., and Coombs, M. G., 1982, "Hightemperature Ceramic Heat Exchanger Element for A Solar Thermal Receiver," Journal of Solar Energy Engineering, 104: 305-09.

https://doi.org/10.1115/1.3266322

Sunden, B., 2005, "High Temperature Heat Exchangers (HTHE)," Proceedings of the 5th International Conference on Science, Engineering and Technology, VIT University, Vellore, India.

Takase, K., Furukawa, H., and Nakano, K., 2002, "A Preliminary Study of An Inter-cooled and Recuperative Microgasturbine Below 300 kW,"
ASME Turbo Expo 2002: Power for Land, Sea, and Air, 1009-1016. American Society of Mechanical Engineers, Amsterdam, Netherlands. https://doi.org/10.1115/GT2002-30403

Treece, B., Vessa, P., and McKeirnan, R., 2002, "Microturbine Recuperator Manufacturing and Operating Experience," ASME Turbo Expo 2002: Power for Land, Sea, and Air, 1017-1023. American Society of Mechanical Engineers, Amsterdam, Netherlands.

https://doi.org/10.1115/GT2002-30404

Tsuji, H., 2003, High Temperature Air Combustion: from Energy Conservation to Pollution Reduction, CRC Press, Boca Raton, FL.

United performance metals, 2018, "Alloy 625 Inconel Supplied in Sheet, Coil, Bar \& Plate," https://www.upmet.com/products/nickelalloys/alloy-625 (accessed March 31, 2018).

Utriainen, E., and Sundén, B., 2002, "Evaluation of The Cross Corrugated and Some Other Candidate Heat Transfer Surfaces for Microturbine Recuperators," Journal of Engineering for Gas Turbines and Power, 124: 550-560.

https://doi.org/10.1115/1.1456093

Visaria, M., Mudawar, I., and Pourpoint, T., 2011, "Enhanced Heat Exchanger Design for Hydrogen Storage Using High-pressure Metal Hydride: Part 1. Design Methodology and Computational Results," International Journal of Heat and Mass Transfer, 54: 413-423. https://doi.org/10.1016/j.ijheatmasstransfer.2010.09.029

Wilson, M. A., Recknagle, K., and Brooks, K., 2005, "Design and Development of A Low-Cost, High Temperature Silicon Carbide MicroChannel Recuperator." ASME Turbo Expo 2005: Power for Land, Sea, and Air, 1029-1034. American Society of Mechanical Engineers, Reno, Nevada, USA.

https://doi.org/10.1115/GT2005-69143

Xiao, G., Yang, T., Liu, H., Ni, D., Ferrari, M. L., Li, M., Luo, Z., Cen, K., and Ni, M., 2017, "Recuperators for Micro Gas Turbines: A review," Applied Energy, 197: 83-99.

https://doi.org/10.1016/j.apenergy.2017.03.095

Zhang, S., and Seiya, W., 2015, "3D Printing as An Alternative Manufacturing Method for The Micro Gas Turbine Heat Exchanger," Duke University.

Zhang, X., Arie, M., Deisenroth, D., Shooshtari, A., Dessiatoun, S., and Ohadi, M., 2015, "Impact of Additive Manufacturing on Performance Enhancement of Heat Exchangers: A Case Study on An Air-to-Air Heat Exchanger for High Temperature Applications." IX Minsk International Seminar on Heat Pipes, Heat Pumps, Refrigerators, Power Sources, Minsk, Belarus.

Zhang, X., Tiwari R., Shooshtari A., and Ohadi, M., 2018, "An Additively Manufactured Metallic Manifold-Microchannel Heat Exchanger for High Temperature Applications," Applied Thermal Engineering, under review. 